\title{
RNA interference: concept to reality in crop improvement
}

\author{
Satyajit Saurabh · Ambarish S. Vidyarthi · \\ Dinesh Prasad
}

Received: 14 December 2013 / Accepted: 21 December 2013 / Published online: 9 January 2014

(C) Springer-Verlag Berlin Heidelberg 2014

\begin{abstract}
The phenomenon of RNA interference (RNAi) is involved in sequence-specific gene regulation driven by the introduction of dsRNA resulting in inhibition of translation or transcriptional repression. Since the discovery of RNAi and its regulatory potentials, it has become evident that RNAi has immense potential in opening a new vista for crop improvement. RNAi technology is precise, efficient, stable and better than antisense technology. It has been employed successfully to alter the gene expression in plants for better quality traits. The impact of RNAi to improve the crop plants has proved to be a novel approach in combating the biotic and abiotic stresses and the nutritional improvement in terms of bio-fortification and bio-elimination. It has been employed successfully to bring about modifications of several desired traits in different plants. These modifications include nutritional improvements, reduced content of food allergens and toxic compounds, enhanced defence against biotic and abiotic stresses, alteration in morphology, crafting male sterility, enhanced secondary metabolite synthesis and seedless plant varieties. However, crop plants developed by RNAi strategy may create biosafety risks. So, there is a need for risk assessment of GM crops in order to make RNAi a better tool to develop crops with biosafety measures. This article is an attempt to review the RNAi, its biochemistry, and the achievements attributed to the application of RNAi in crop improvement.
\end{abstract}

\footnotetext{
S. Saurabh · D. Prasad $(\bowtie)$

Department of Biotechnology, Birla Institute of Technology,

Mesra, Ranchi 835125, India

e-mail: dinesh@bitmesra.ac.in

A. S. Vidyarthi

Department of Biotechnology, Birla Institute of Technology,

Patna, Bihar, India
}

Keywords RNAi - miRNA - siRNA - Crop improvement · Seedless fruit $\cdot$ Morphology alteration $\cdot$ Male sterility Stress tolerance $\cdot$ Defence enhancement

\section{Introduction}

RNAi is an evolutionarily conserved defence mechanism occurring naturally against double-stranded RNA (dsRNA) that can target cellular and viral mRNAs. In this biological process small RNA interferes with the translation of target mRNA transcript eventually suppressing the gene expression. The small non-coding RNAs are the cleavage product of dsRNA called microRNA (miRNA) and small interfering RNA (siRNA). The cleavage is carried out by a ribonuclease called DICER or Dicer-like enzyme (Pare and Hobman 2007). The small non-coding RNAs in association with RNA-induced silencing complex (RISC) (Redfern et al. 2013; Wilson and Doudna 2013), Argonaute (AGO) (Riley et al. 2012; Ender and Meister 2010) and other effector proteins lead to the phenomenon called RNAi illustrated in Fig. 1. The discovery of this phenomenon has transformed it into a powerful tool of genetic engineering and functional genomics.

The improvement of crop plants by alteration of traits using traditional plant breeding programme is time consuming and labour intensive. Since last two decades the researchers are switching towards biotechnological approaches for crop improvement. The manipulations in gene expression for quality traits in crop can now easily be achieved by RNAi. It can be employed by identifying the target gene(s) developing vectors as an RNAi construct, transforming plant and finally screening and evaluating the traits (Table 1). The abbreviation of RNAi-relevant terms used in this review are summarized in Table 2. The 


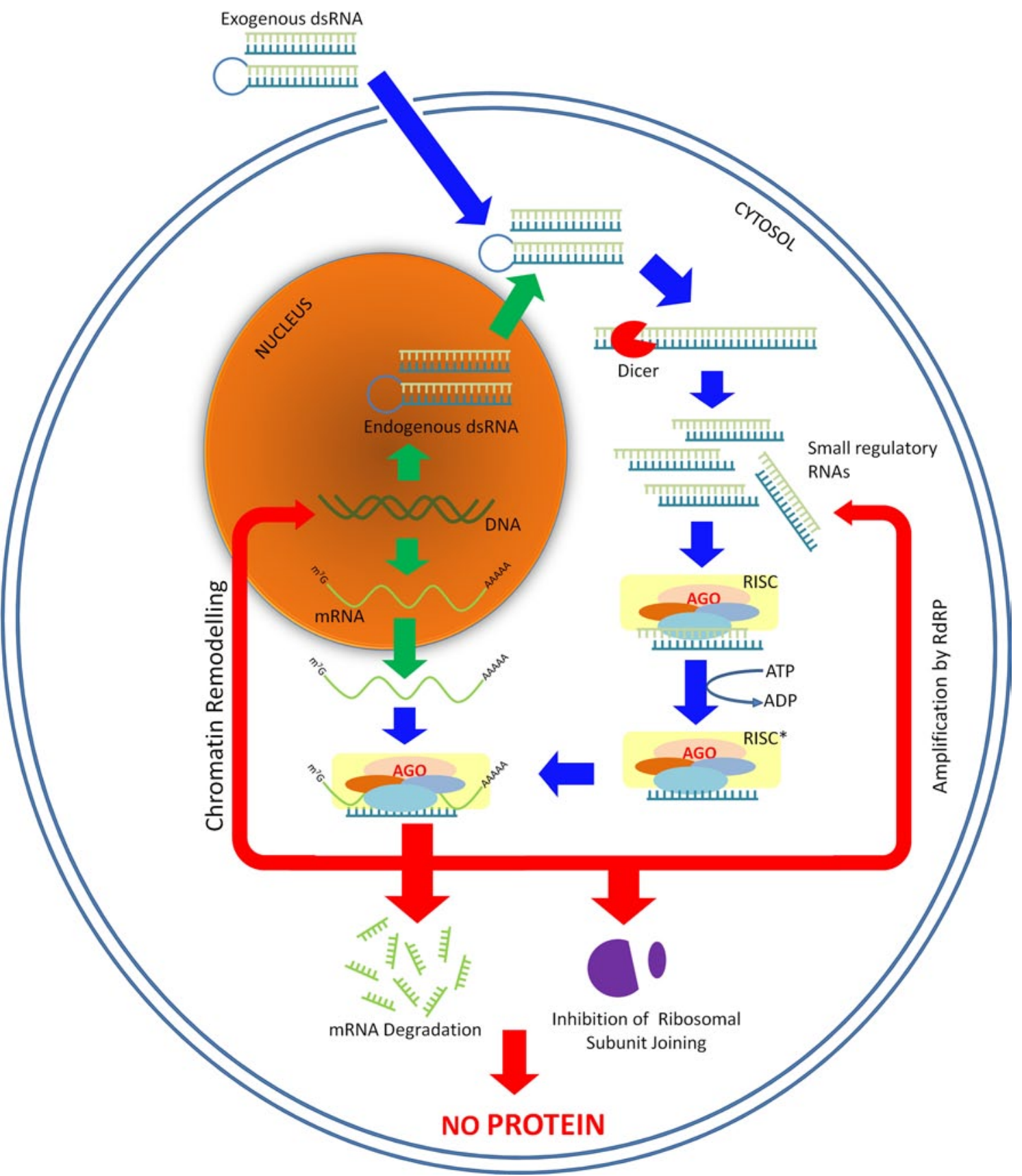

Fig. 1 The schematic representations of pathways involved in biogenesis of small regulatory RNAs (siRNAs, miRNAs) and their role in mechanisms for RNA interference. Green arrows denote natural pathway of molecular biology. Blue arrows denote the pathway involved in biogenesis of activated small regulatory RNAs from

useful links as tabulated in Table 3 may assist in performing genetic engineering with RNAi. The RNAi construct is designed to express self-complementary sequence homologous to the target gene in form of hairpin RNA (hpRNA). The insertion of a spacer sequence (usually an intron) between the two complementary sequences, expressing intron-hairpin RNA (ihpRNA), enhances the double stranded RNA (dsRNA). Red arrows denote the RNA interference-mediated pathways leading to gene silencing. RISC RNA induced silencing complex, RISC* activated RNA induced silencing complex, $A G O$ argonaute proteins, $R d R P$ RNA-dependent RNA polymerase

efficiency (Wesley et al. 2001). The tailoring of construct for various strengths and patterns of gene silencing is of most important for genetic engineering (Fig. 2). For specific plants and applications, the use of appropriate vector, promoter, marker, and transformation method are needed for enhanced efficiency of RNAi. The potential of RNAi as the most efficient tool for genetic engineering to 
Table 1 A roadway to perform genetic engineering with RNA interference

\begin{tabular}{|c|c|}
\hline STEP I & $\begin{array}{l}\text { Identification of target gene and its related pathway } \\
\text { - Genome sequencing } \\
\text { - Applying bioinformatic tools } \\
\text { - Analysis of transcriptome, proteome and metabo- } \\
\text { lome }\end{array}$ \\
\hline STEP II & $\begin{array}{l}\text { Vector development to prepare RNAi constructs and } \\
\text { screening for RNAi constructs } \\
\text { - Selection of suitable vector } \\
\text { - Selection of suitable promoter } \\
\text { - Screening by selectable markers }\end{array}$ \\
\hline STEP III & $\begin{array}{l}\text { Transforming and screening transgenic plant } \\
\text { - Delivery of RNAi } \\
\text { - Tissue culture of transgenic line(s) } \\
\text { - Screening and selection of transformed plants }\end{array}$ \\
\hline STEP IV & $\begin{array}{l}\text { Evaluation of transgenic lines for improved quality } \\
\text { - Morphological evaluation } \\
\text { - Transcriptome evaluation } \\
\text { - Biochemical evaluation }\end{array}$ \\
\hline
\end{tabular}

knockdown the gene expression is summarized as its benefits in Table 4.

From the beginning of twenty-first century, role played by small non-coding RNAs in regulatory processes of posttranscriptional gene silencing (PTGS) and transcriptional gene silencing (TGS) continues to be investigated one after another. The investigations revealed the outcome of gene silencing leading to the understanding of mechanisms involved. Till date several classes of small non-coding regulatory RNAs have been discovered in different model organisms. These include miRNA, siRNA, piRNA (PIWIinteracting RNA), qiRNA (QDE-2-interacting RNA), svRNA (small vault RNA), etc., having different biochemical approaches for their biogenesis (Aalto and Pasquinelli 2012).

In brief, the process for the biogenesis of miRNA and siRNA initially differs to form their respective dsRNA precursors. Later on, both siRNAs and miRNAs are produced by the cleavage of dsRNA precursors by Dicer or Dicerlike enzyme, a member of the RNase III family of dsRNAspecific endonucleases (Bernstein et al. 2001; Hutvagner et al. 2001). Finally, the small non-coding RNAs (miRNAs and siRNAs) in association with RNA-induced silencing complex (RISC), Argonaute (AGO) and other effector proteins lead to gene silencing.

\section{MicroRNAs (miRNAs)}

The miRNA was first described as regulator of the juvenileto-adult transition in Caenorhabditis elegans (Lee et al. 1993; Reinhart et al. 2000). In past few years, it was found to regulate several developmental transitions in plants also (Wu and Poethig 2006; Wu et al. 2009) like Arabidopsis thaliana (Aukerman and Sakai 2003; Sieber et al. 2007), Zea mays (Chuck et al. 2007a, b), Antirrhinum majus and Petunia hybrida (Cartolano et al. 2007).

The miRNAs are endogenous $\sim 23$ nt RNAs transcribed by RNA Polymerase II (Lee et al. 2004), emerging as the most abundant and important class of small regulatory RNAs that mediate important gene-regulatory events by pairing to the mRNAs of protein-coding genes to direct their repression. Till date miRNAs are reported in plants, animals, unicellular algae and even viruses. In plants, the processing of both pri-miRNA to pre-miRNA and premiRNA to mature miRNA involves a homolog of dicer, DCL1.

After generation of mature miRNAs, the miRNAinduced silencing complex (miRISC) having Argonaute and other effector proteins, is recruited. The miRISC can cause miRNA-mediated gene silencing by target mRNAs through antisense base-pairing with specific miRNAs. The silencing mechanisms can differ depending upon cellular condition, cell type, developmental stage, target site, etc.

Huntzinger and Izaurralde (2011) proposed that the gene expression can be down-regulated by (1) the formation of miRNA complex which inhibits translational initiation or ribosome subunit joining, induce premature degradation of the nascent polypeptide chain and increase ribosome drop off; or (2) inducing deadenylation and destabilization of target mRNA.

\section{Short-interfering RNAs (siRNAs)}

Gene silencing by RNAi can be initiated by long dsRNA or short-hairpin RNA (shRNA) precursors, which are homologous in sequence to the gene to be silenced (Fire 1999; Tuschl 2001). The entry of long dsRNA such as an introduced transgene, a rogue genetic element (like transposable elements or repetitive elements) or a viral intruder inside the cytosol triggers the RNAi pathway of cells by recruiting the enzyme dicer (Bernstein et al. 2001). The dicer cleaves the dsRNA into short, 21-25 bp fragments known as siRNA (Hamilton and Baulcombe 1999).

The siRNAs are short, 5'-phosphorylated dsRNAs with two nucleotide overhangs at the $3^{\prime}$ end, generated by dicer from longer dsRNAs (Bernstein et al. 2001; Elbashir et al. 2001). The siRNA-induced silencing complex (siRISC) is recruited to distinguish between the two siRNA strands as either sense or antisense and resulting in the degradation of sense strands (with exactly the same sequence as the target gene). The siRISC is then incorporated into the antisense strand of siRNA with the target messenger RNAs (mRNA) in a sequence-specific manner. The target mRNA is cleaved by RISC having Argonaute (AGO) and other effector proteins, inhibiting the process of translation. The activated RISC can repeatedly participate in mRNA degradation and 
Table 2 Abbreviations

\begin{tabular}{|c|c|}
\hline RISC & RNA-induced silencing complex \\
\hline AGO & Argonaute \\
\hline ihpRNA & Intron-hairpin RNA \\
\hline PTGS & Post-transcriptional gene silencing \\
\hline piRNA & PIWI-interacting RNA \\
\hline qiRNA & QDE-2-interacting RNA \\
\hline svRNA & Small vault RNA \\
\hline СMT3 & Cytosine methyltransferase \\
\hline ARF & Auxin response factor \\
\hline GA & Gibberellic acid \\
\hline$\beta$-Hex & $\beta$-D- $N$-Acetylhexosaminidase \\
\hline Mshl & MutS HOMOLOG 1 \\
\hline GWD & Glucan, water dikinase \\
\hline SEX4 & Phosphoglucan phosphatase \\
\hline$L G C-1$ & Low glutenin content 1 \\
\hline SPS & Sucrose-phosphate synthase \\
\hline Suc6P & Sucrose-6-phosphate \\
\hline SPP & Sucrose phosphatase \\
\hline VI & Vacuolar invertase \\
\hline 2-PRENCSO & $S$-2-propenyl-L-cysteine sulfoxide \\
\hline 1-PRENCSO & trans-S-1-Propenyl-L-cysteine sulfoxide \\
\hline BOAA & Beta- $N$-oxalyl-ami-noalanine-L-alanine \\
\hline ULGCS & Ultra-low gossypol cottonseed \\
\hline TSNA & Tobacco-specific nitrosamine \\
\hline NNN & $N^{\prime}$-Nitrosonornicotine \\
\hline $\mathrm{BoHc}$ & $45 \mathrm{kDa}$ C-terminal half of the heavy chain of botulinum type A neurotoxin \\
\hline LDLRAP1 & Low-density lipoprotein receptor adapter protein 1 \\
\hline CETS & CENTRORADIALIS/TERMINAL FLOWER 1/SELF-PRUNING \\
\hline PEBP & Phosphatidylethanolamine binding protein \\
\hline FT & FLOWERING LOCUS T \\
\hline TFL1 & TERMINAL FLOWER I \\
\hline $\mathrm{Cg} 1$ & Corngrass 1 \\
\hline $\mathrm{CHI}$ & Chalcone isomerase \\
\hline TP & Tyrosine phosphatase \\
\hline MSP & Mitochondrial stress-70 protein precursor \\
\hline PDR & Pathogen-derived resistance \\
\hline $\mathrm{CP}$ & Coat protein \\
\hline BNYVV & Beet Necrotic Yellow Vein Virus \\
\hline PVY & Potato Virus Y \\
\hline PRSV-W & Papaya Ring Spot Virus type W \\
\hline PPV & Plum Pox virus \\
\hline CGMMV & Cucumber Green Mottle Mosaic Virus \\
\hline TSV & Tobacco Streak Virus \\
\hline ACMV & African Cassava Mosaic Virus \\
\hline CBSD & Cassava Brown Streak Disease \\
\hline CBSV & Cassava Brown Streak Virus \\
\hline CBSUV & Cassava Brown Streak Uganda Virus \\
\hline MYMIV & Mungbean Yellow Mosaic India Virus \\
\hline TYLC & Tomato Yellow Leaf Curl Virus \\
\hline RTBV & Rice Tungro Bacilliform Virus \\
\hline CTV & Citrus Tristeza Virus \\
\hline
\end{tabular}


Table 2 continued

Table 3 Useful links that assist to perform genetic engineering with RNAi

$\begin{array}{ll}\text { PSTVd } & \text { Potato Spindle Tuber Viroid } \\ \text { ABA } & \text { Abscisic acid } \\ \text { FTA or FTB } & \text { Farnesyl transferase genes } \\ \text { C4H } & \text { Cinnamate 4-hydroxylase } \\ \text { C3H } & \text { Coumarate 3-hydroxylase } \\ \text { HCT } & \text { Hydroxycinnamoyl CoA-shikimate/quinate transferase } \\ \text { CCoAOMT } & \text { Caffeoyl-CoA-3- } O \text {-methyltransferase } \\ \text { CCR } & \text { Cinnamoyl CoA reductase } \\ \text { F5H } & \text { Ferulate 5-hydroxylase } \\ \text { COMT } & \text { Caffeic acid-3-O-methyltransferase } \\ \text { CAD } & \text { Cinnamyl alcohol dehydrogenase } \\ \text { PPO } & \text { Polyphenol oxidase } \\ \text { BBrMV } & \text { Banana Bract Mosaic Virus }\end{array}$

a

b

c

d

e

f

g

h

j

$\mathrm{k}$

\section{Resources on RNAi}

http://www.ambion.com/techlib/resources/RNAi/

http://srna-tools.cmp.uea.ac.uk/plant/

Computation model to predict gene function

http://www.sciencedaily.com/releases/2010/01/100131142436.html

Target finder

http://www.ambion.com/techlib/misc/siRNA_finder.html

http://bioinfo3.noble.org/psRNATarget/

For careful selection of an insert gene sequence

http://bioinfo2.noble.org/RNAiScan/RNAiScan.html

RNAi design tool

http://www.ccts.uky.edu/Research/microRNA/miRNAResearchHome.aspx

https://rnaidesigner.invitrogen.com/sirna/

http://biotools.idtdna.com/rnai/

http://wmd.weigelworld.org/

http://www.protocol-online.org/prot/Molecular_Biology/RNA/RNA_ Interference/siRNA_Design_Rules/

siRNA selection

http://hydra1.wistar.upenn.edu/Projects/siRNA/siRNAindex.htm

http://jura.wi.mit.edu/siRNAext/register.php

Find restriction sites in given gene sequence, NEB cutter V2.0 (New England Biolabs) http://tools.neb.com/NEBcutter2/

miRNA database

http://www.mirbase.org/

http://bioinformatics.cau.edu.cn/PMRD/

http://www.misolrna.org./

http://ted.bti.cornell.edu/cgibin/TFGD/sRNA/home.cgi

M. truncatula RNAi database

https://mtrnai.msi.umn.edu/

Arabidopsis Genomic RNAi Knock-out Line Analysis (AGRIKOLA) project

http://www.agrikola.org/index.php?o=/agrikola/html/index

Probabilistic functional gene network of Arabidopsis thaliana

http://www.functionalnet.org/aranet/ 


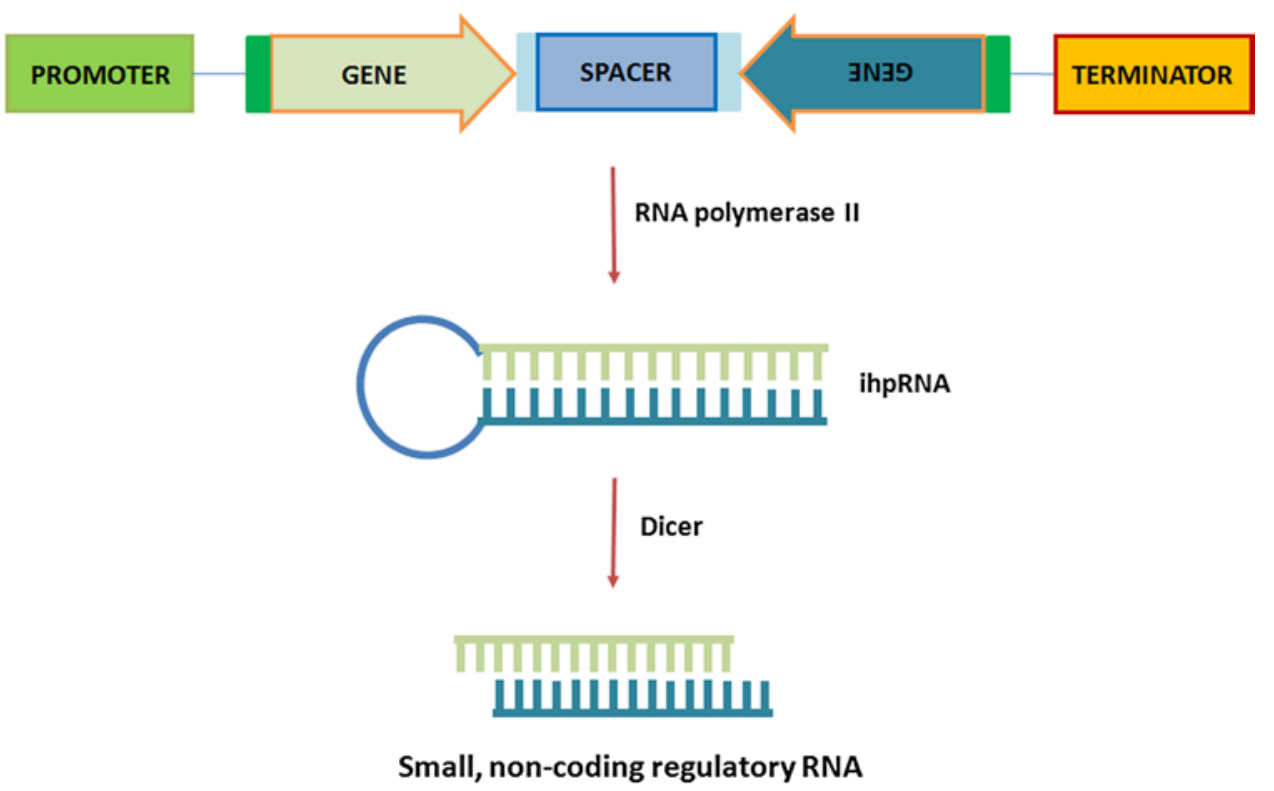

Fig. 2 Tailoring of vectors for more efficient, precise and stable RNA interference. In transformed plants, the expression of gene (in sense and antisense orientations) along with the spacer sequence forms ihpRNA. Initially, ligase-based vectors such as pHANNIBAL and pKANNIBAL were used for RNAi constructs. Now, the vectors used for RNAi construct are based upon Gateway Vectors like
pHELLSGATE, pSTARGATE and pWATERGATE. In many RNAi constructs constitutive promoters like $35 \mathrm{~s}$ CaMV, plant pathogen promoters, Rice actin promoter, Plant ubiquitin promoter (Ubi), Maize alcohol dehydrogenase 1 promoter (Adh-1) can efficiently drive foreign gene expression in plant cells

Table 4 Benefits of RNAi for gene silencing in plants

a Precise

b Efficient

c User friendly

d High-throughput

e Stable

f Flexible

g Better than antisense

No off-target effects reported. But may affect the feedback loops

CSIRO Plant Industry has reported that 70-100\% of transformed plants show the silencing phenotype

By employing several user-friendly tools available to perform RNAi in plants

High-throughput vectors are designed to make an hpRNAi construct (Wesley et al. 2001, Xu et al. 2010, Yan et al. 2012)

hpRNAi has been shown to be stably inherited over several generations (Kusaba et al. 2003)

Individual or multiple genes can be silenced with single construct. Allen et al. (2004) have shown effective silencing of two genes from one hpRNAi construct

The highest silencing obtained with an antisense construct was only as good as the least silenced plant with hpRNAi (Wesley et al. 2001). In comparing the ability of sense, antisense, dsRNA at generating RNA-mediated virus resistance via PTGS in tobacco and silencing of an endogenous GUS reporter gene in rice; Waterhouse et al. 1998, has shown that in both cases duplex RNA was more effective than either sense or antisense RNA at silencing the target gene

inhibiting protein synthesis results into post-transcriptional gene silencing (PTGS).

Not only this, siRNAs also have a role as co-transcriptional silencers of gene expression by chromatin regulation (Burkhart et al. 2011; Fagegaltier et al. 2009). Ossowski et al. (2008) reported that siRNA recruits several DNA- and histone-modifying proteins including the cytosine methyltransferase, CHROMOMETHYLASE3 (CMT3), which together mediate the formation of a silent chromatin state with minimal transcriptional activity; leading to transcriptional gene silencing (TGS).

\section{Applications in crop improvement}

The demand for plants increases with the rapid increase in population and at the same time population is facing the problems of food security, malnutrition, and famine (Godfray et al. 2010). To overcome these problems, the interplay of genetic engineering with plant physiology, proteomics and genomics will be needed (Mittler and Blumwald 2010; Tester and Langridge 2010). This has been effectively demonstrated in terms of high-yielding varieties with improved traits (Sharma et al. 2002). The RNAi approach and its 
contribution in achieving desired traits by manipulating the genetic expression have proven its potential in crop improvement.

\section{Seedless fruit development}

It is well known that the phytohormone plays a key role in regulation of transition between flowering, fertilization and fruiting. Parthenocarpy is potentially useful for producing vegetables and fruits when pollination or fertilization is affected due to extreme temperatures, as in winter (Tomes 1997) or, more generally, to ensure yield stability in case of unfavourable pollination conditions. Recent studies have shown that seedlessness can increase the texture and shelf life of fruits, for instance in the case of watermelon and eggplant (Pandolfini 2009). In watermelon, it was observed that seeds are the origin of fruit deterioration. Thus, replacing seeds and seed cavities with edible fruit tissue is desirable (Varoquaux et al. 2000) and can be of great value for consumers, the processing industry and breeding companies. In addition, it has been shown that seed development in fruits restricts the yield in cucumber (Tiedjens 1928; Denna 1973) and tomato (Falavigna and Soressi 1987).

Two members of ARF family, ARF8 of A. thaliana and $A R F 7$ of tomato show high level of expression in non-pollinated flowers and are down-regulated after pollination. De Jong et al. (2009) indicated that SlARF7 acts as a modifier of both auxin and gibberellin responses during tomato fruit set and development. Normally, SlARF7 transcript levels are reduced after pollination and fertilization (Vriezen et al. 2008; De Jong et al. 2009). Reduction of SlARF7 transcript levels by an RNAi approach may release the repression of the auxin and GA signalling pathways that are imposed by SIARF7 independently of pollination and fertilization, resulting in the partial activation of these pathways and thus in parthenocarpic fruit growth in tomato (Solanum lycopersicum). Hence, the fertilization-dependent step of the auxin signalling transduction pathway may be bypassed, which might be necessary to initiate cell division activity and stimulate GA biosynthesis.

\section{Enhanced shelf life}

Fruits and vegetables are more prone to spoilage than cereals due to their nature and composition, and this spoilage results in inedible waste. In spite of being one of the largest producer of fruits and vegetables, India loses about $30 \%$ of total fruits and vegetables produced due to spoilage (Agricultural Research Data Book 2004). So, there is a necessity for increase in shelf life of vegetables and fruits as another essential agronomic trait which may minimize the deterioration and spoilage of vegetables and fruits, thus minimizing the horticultural loss.
The shelf life in tomato has been increased by silencing of genes associated with either ethylene production or ripening. Xiong et al. (2005) used RNAi technology to increase shelf life in tomato. They introduced a unit of dsRNA and blocked the expression of ACC oxidase gene in tomato. The ethylene production rate in ripened fruits and leaves of transgenic plants was found to be significantly inhibited, ensuring a prolonged shelf life of tomato. On the other hand, Meli et al. (2010) have suppressed two ripening-specific $\mathrm{N}$-glycoprotein modifying enzymes, $\alpha$-mannosidase ( $\alpha$-Man) and $\beta$-D- $N$-acetylhexosaminidase $(\beta$-Hex) after their identification in tomato. They have shown that RNAi suppression of these genes enhances shelf life of tomato, through reduced rate of softening.

\section{Male sterility and fertility}

The development of male sterility is one of the most important traits chosen to ensure purity in order to construct hybrid plant for hybrid seed production. Several methods based on conventional as well as genetic engineering are used by plant biologists for the abortion of pollens from various crop species. Today, genetic engineering is used to produce male-sterile plant varieties like tobacco and tomato through RNA interference. Not only this, RNAi can also be employed to restore the fertility of male-sterile plants (Nizampatnam and Kumar 2011).

Recently, Zhu and Deng (2012) have highlighted the relationship of small RNA (osa-smR5864) with photoperiod- and temperature-regulated male sterility.

In plants, MutS HOMOLOG 1 (Mshl) is a nuclear gene product that maintains genome stability in both mitochondria and plastids. Under abiotic stresses, the suppression of $M s h 1$ triggers a plastidial response that involves non-genetic inheritance and alters numerous plant metabolic pathways (Xu et al. 2012). Sandhu et al. (2007) also used RNAi technology to disrupt the expression of Mshl in tobacco and tomato which resulted in rearrangements in the mitochondrial DNA associated with naturally occurring cytoplasmic male sterility. The breeding through these RNAi lines may have few drawbacks like the hybrid may carry the construct in F1 generation leading to severe effects.

\section{Nutritional improvement}

\section{Biofortification}

The diet of over two-thirds of the world's population lacks one or more essential mineral elements (White and Broadley 2009). RNAi confers the biofortification of plants such as tomatoes with dietary antioxidants (Niggeweg et al. 2004) and essential elements like $\mathrm{Zn}, \mathrm{Mg}, \mathrm{Cu}, \mathrm{Se}, \mathrm{Ca}, \mathrm{Fe}, \mathrm{I}$, S, P, etc., (Table 6). 
The production of potential pharmaceutical compounds using genetic engineering and transient expression systems such as agro-infiltration, virus infection and magnification (Obembe et al. 2011) is known as molecular pharming or bio-pharming. It focuses mainly on the biosynthesis of proteins and secondary metabolites which are very useful for humans, but are expensive in the market. Various therapeutics and nutraceuticals are being produced using molecular pharming (Obembe et al. 2011). The production potential of RNAi for these products has been reported in many papers, some of which are discussed in this article.

In 2005, Hüsken et al. had used RNAi to reduce the levels of sinapate esters by $76 \%$ in transgenic canola seeds of the T3 generation by inhibiting UDPGlc:sinapateglucosyltransferase gene activity. Removal of sinapate esters enhances the flavour of canola seeds exhibiting the utility of RNAi in over production/over-expression of certain gene to get the desired trait.

Plants can be improved by RNAi technology to increase the starch content in the leaves. It has been shown that starch phosphorylation and dephosphorylation are critical components of leaf starch degradation, where glucan, water dikinase (GWD) adds phosphate to starch, and phosphoglucan phosphatase (SEX4) removes these phosphates. In maize, the pathway of leaf starch degradation is less well characterized (Weise et al. 2011). Weise et al. (2012) had manipulated phosphate metabolism in Zea mays (maize) and $A$. thaliana using RNAi constructs to increase the starch content.

Kusaba et al. 2003 were able to reduce the level of glutenin employing RNAi-mediated gene silencing by GluB hairpin RNA and produced a rice variety called $L G C-1$ (low glutenin content 1), a relief to the kidney patients unable to digest glutenin.

The consumption of alpha-linolenic acid (18:3) was found to be unhealthy for human as well as animals. The reduction of alpha-linolenic acid (18:3) is good to improve soybean oil flavour and stability with reduced need for its hydrogenation. The linoleic acid (18:2) is converted into alpha-linolenic acid (18:3) in presence of enzyme omega-3 fatty acid desaturase. Flores et al. (2008) have constructed Hairpin RNA for the down regulation of omega-3 fatty acid desaturase (GmFAD3A, GmFAD3B and $G m$ FAD3C), using glycinin promoter for seed-specific silencing. Transgenic soybean seed has been reported to have 1-3\% of alphalinoleic acid in comparison with 7-10\% in non-transgenic soybean seed.

Sucrose biosynthesis involves two enzymatic steps: sucrose-phosphate synthase (SPS) catalyses the synthesis of sucrose-6-phosphate (Suc6P), which is further, hydrolysed by sucrose phosphatase (SPP) to yield sucrose and inorganic phosphate $(\mathrm{Pi})$. Storage of potato tubers at low temperature $\left(4{ }^{\circ} \mathrm{C}\right)$ leads to the accumulation of glucose and fructose in a process called 'cold sweetening'. Chen et al. (2008) used CaMV 35S promoter-driven hairpin RNAi construct containing part of the coding region of the tobacco NtSPP2 gene to reduce SPP expression in transgenic potato tubers. They reported that Suc6P accumulates in RNAi-silenced sucrose phosphatase (SPP) potato tubers upon cold storage at $4{ }^{\circ} \mathrm{C}$. They have revealed from northern analysis that cold-induced expression of vacuolar invertase (VI) was blocked in SPP-silenced tubers explaining a reduced sucrose-to-hexose conversion. Suc6P levels were found to be negatively correlated with VI expression.

Gil-Humanes et al. (2008) used RNAi technology to silence the expression of specific $\gamma$-gliadins and reported the reduced level of $\gamma$-gliadins by about $55-80 \%$ in the bread wheat cultivar 'Bobwhite' lines (BW208) and by about 33-43\% in the 'Bobwhite' lines (BW2003). Further, Gil-Humanes et al. (2012) reported that down-regulation of gamma-gliadins by RNAi in wheat lines produced a compensatory effect in the rest of the gluten proteins, with no statistically significant changes in the total content of gliadins, whereas the glutenin content was increased. As a consequence, the total protein content was slightly increased in most of the transgenic lines.

\section{Allergen and toxin elimination}

Food allergy is an exaggerated immune response of our body triggered by allergens present in food such as peanuts, apple, mango or some other specific food. So, there is a need to reduce or eliminate the content of allergens from our food. Not only this, there is also a need to develop plants free from toxic substances as the natural toxins are present in a wide variety of plants commonly consumed as food. These toxic substances when ingested in significant amount or when they are not processed appropriately can be potentially harmful to human health causing food poisoning. The elimination of allergens and toxic substances can be achieved by employing RNA interference that may alter the biosynthesis of allergens by altering its biochemical pathway to improve the food quality by minimizing the risk of food allergy and toxicity.

RNAi was employed to inhibit the expression of major apple allergen, Mal d1 that belongs to a group of pathogenesis-related protein PR10. The Mal d1 expression has been reduced successfully by Gilisen et al. (2005) through RNAi-based gene silencing. In 2008, Dodo et al. demonstrated about $25 \%$ reduction of Ara h 2 content in crude peanut extract by down-regulating its expression through RNAi using its hpRNA construct. In peanut, the Ara $\mathrm{h} 2$ is one of the most allergic protein present out of 7 allergenic proteins. To remove Lyc e3 from tomato, Le et al. (2006) have demonstrated an efficient silencing of Lyc e3, a tomato allergen that encodes a nonspecific lipid transfer protein in the RNAi-silenced tomato plants. 
Siritungam and Sayre (2003) have reduced the linamarin content, a cyanogenic substance in cassava plants. Jørgensen et al. (2005) used RNAi to suppress the cytochrome P450 enzyme production inhibiting the biosynthesis of linamarin and lotaustralin, and generated transgenic cassava (Manihot esculenta) plants with elimination of less than $1 \%$ of cyanogenic glucosides from leaves and $92 \%$ reduction of cyanogenic glucosides from tubers.

Allium species synthesize a unique set of cysteinederived secondary sulphur metabolites such as $S$-alk (en) yl-L-cys sulfoxides, which include $S$-2-propenyl-L-cysteine sulfoxide (alliin or 2-PRENCSO) and trans-S-1-propenyl-Lcysteine sulfoxide (isoalliin or 1-PRENCSO). On disruption of tissues, these cysteine derivatives are cleaved by alliinase (EC 4.4.1.4) into sulfenic acids and volatile sulphur compounds giving characteristic flavour and bioactivity. The conversion of 1-propenyl sulfenic acid to propanthial $S$-oxide (tear-inducing, lachrymatory factor, LF) is mediated by an enzyme, named lachrymatory factor synthase (LFS). Eady et al. (2008) suppressed lfs gene by hpRNAi using $35 \mathrm{~S}$ CaMV promoter reducing LFS activity in wounded onion resulting in the production of tearless onion.

People of countries like India, Bangladesh and Ethiopia, consume grass pea (Lathyrus sativus). Grass pea or chickling pea contains a neurotoxin, beta- $N$-oxalyl-ami-noalanine-L-alanine (BOAA), which can cause paralytic disease called lathyrism (Spencer et al. 1986). BOAA is also known to impart immunity to plant under extreme stress conditions, but the use of RNAi technology in bringing down the level of BOAA to an appropriate concentration can render the crop safe for its consumption (Angaji et al. 2010).

Cotton seeds are rich in dietary protein but unsuitable for human consumption because of their toxic terpenoid content, gossypol. Gossypol is a cardio and hepatotoxic terpenoid, which makes it unsafe for human and monogastric animal consumption (Risco and Chase 1997). Gossypol is also important in plant defence mechanism as it provides protection against insects and pathogens. So utilizing seedspecific promoter does not affect terpenoid level in leaves and other parts of cotton plant. RNAi has been used to produce cotton stocks with seeds containing lower levels of delta-cadinene synthase, a key enzyme in gossypol biosynthesis pathway, without affecting the enzyme's production in other parts of the plant, where gossypol is important in preventing damage from plant pests. It has been reported that the transgenic cotton seeds have about $99 \%$ reduced gossypol content as compared to wild types (Sunilkumar et al. 2006). Recently, Rathore et al. (2012) reported that RNAi-knockdown of delta-cadinene synthase gene was used to engineer cotton plants that produced ultra-low gossypol cottonseed (ULGCS). They also showed that RNAi-mediated ULGCS trait exhibited multi-generational stability.
As nor-nicotine is the precursor of a carcinogenic, tobacco-specific nitrosamine (TSNA), $N^{\prime}$ nitrosonornicotine (NNN) (Hecht 1998) and the conversion of nicotine to nor-nicotine is mediated by an enzyme nicotine demethylase. The inhibition of nicotine demethylase activity is an effective mean of decreasing significantly the level of defined carcinogen present in tobacco products. Gavilano et al. (2006) used RNAi for silencing the $N$-demethylase (CYP82E4) gene for suppressing the conversion of nicotine to nor-nicotine in tobacco (Nicotiana tabacum). Further, Lewis et al. (2008) developed RNAi-silenced nicotine demethylase transgenic lines of burley tobacco line (DH98-325-5) exhibiting sixfold decrease in nor-nicotine content.

\section{Therapeutics}

Recent finding has proved the role of RNAi in therapeutics. Yuki et al. (2012) demonstrated utilization of efficient advance MucoRice system for generating highly immunogenic mucosal vaccines. They used RNAi suppression of a combination of major rice endogenous storage proteins (13 kDa prolamin and glutelin A), and could express highly a vaccine comprising the $45 \mathrm{kDa} \mathrm{C}$-terminal half of the heavy chain of botulinum type A neurotoxin $(\mathrm{BoHc})$, at an average of $100 \mu \mathrm{g}$ per seed (MucoRice-BoHc). MucoRiceBoHc could induce high levels of mucosal immune response when nasally administered together with mucosal adjuvant. Mice were immunized with nasal vaccine composed of $25 \mu \mathrm{g}$ of MucoRice-BoHc and mucosal adjuvant. Results suggested that MucoRice-BoHc with nontoxic chimera adjuvant CTA/LTB has the potential to be used as a promising nasal vaccine against botulism.

Vaucheret and Chupeau (2012) have mentioned exogenous plant miRNAs are present in the sera and tissues of various animals and that these exogenous plant miRNAs are primarily acquired orally, through food intake directly influence gene expression in animals after migration through the plasma/sera and delivery to specific organs. Zhang et al. (2012a) have reported a surprising finding that plant miRNAs acquired orally through food are present in the sera and tissues of various animals and can regulate the expression of target genes in mammals. In the sera of healthy Chinese men and women, MIR168a of rice is found highly enriched plant miRNA. In vitro and in vivo studies have demonstrated that MIR168a could bind to the human/mouse lowdensity lipoprotein receptor adapter protein 1 (LDLRAP1) mRNA, inhibit LDLRAP1 expression in liver decreasing LDL removal from mouse plasma leading to increase in LDL content. This phenomenon shows the therapeutic potential of exogenous supply of plant-derived miRNA to regulate the expression of specific gene in cross-kingdom such as human beings. 


\section{Altered phenotype}

Since antiquity, ornamental plants and flowers are improved by modifying their various traits such as colour, shape and size of flowers and architecture of plants. The alteration in architecture of crop plants may also lead to increase crop yield, e.g. Dwarf Rice. So, there is a need to improve the phenotype of plants and flowers.

\section{Altered architecture}

Plant architecture is a basic agronomic trait shaped by indeterminate and determinate meristems, and their activities subsequently guide different patterns of plant growth (Sussex and Kerk 2001) such as, plant height and canopy, leaf size and number, branches, number of flowers, fruit size and shape, root size and structure, etc., to increase yield in ornamental, fruit and crop plants.

Recently, McGarry and Ayre (2012) reviewed the roles of the genes belonging to the CENTRORADIALIS/TERMINAL FLOWER 1/SELF-PRUNING (CETS) family which share homology to phosphatidylethanolamine binding protein (PEBP) genes. FLOWERING LOCUS T (FT) and TERMINAL FLOWER I (TFL1) of Arabidopsis and orthologs from other species are best-characterized in controlling the balance and distribution of indeterminate and determinate growth. These genes can be manipulated to enhance the crop yield or improve plant/flower morphology. The RNAi had shown its potential by its employment in plants to alter their morphology as per requirement (such as height, inflorescence, branching and size).

In poplar, Rubinelli et al. (2013) over-expressed a unique miRNA gene from maize belonging to the MIR156 family called Corngrass $1(\mathrm{Cg} 1)$ under the control of the cauliflower mosaic virus $35 \mathrm{~S}$ promoter. Transgenics had significantly greater axillary meristem outgrowth, shorter internode length, and up to a $30 \%$ reduction in stem lignin content compared to stem lignin of the wild-type.

Recently, McGarry and Ayre (2012) reported that the HSPp::FT1/FT2-RNAi lines also formed inflorescences, suggesting that FT1 signalling is sufficient for reproductive onset.

\section{Altered colour/scent of flowers}

Nowadays, the demand of flowers has increased for the purpose of decoration and scent. There is a need to develop flowers like lotus, rose, tulip, petunia, orchid and poppy in different colours and scents, as per their demand in market. Many researches are being performed to improve the flowers through gene silencing (Table 5).

Seitz et al. (2007) and Nakatsuka et al. (2010) suggested that reduced accumulation of polyacylated anthocyanins by RNAi could cause modulations of flower colour. In 2005, Nishihara et al. had applied RNAi-mediated silencing of chalcone isomerase (CHI) in tobacco and reported reduced pigmentation and change of flavonoid components in flower petals. In pollen, it showed a yellow colouration which was indicative of accumulation of high levels of chalcone suggesting that $\mathrm{CHI}$ plays a major role in the cyclization reaction from chalcone to flavanone.

\section{Defence improvement}

The evaluation of RNAi from greenhouse studies to field trials provides critical information for successful antiresistance strategies. These strategies could be employed to control the biotic stresses by improving defence mechanism

Table 5 RNAi-mediated improvised defence

\begin{tabular}{|c|c|c|c|c|c|}
\hline S. no. & Defence improvement & Resistance against & Targeted gene & Plant used & References \\
\hline \multirow[t]{2}{*}{1} & \multirow[t]{2}{*}{ Insect resistance } & Helicoverpa armigera & CYPAE14 & Cotton & Mao et al. (2007) \\
\hline & & Corn rootworm & V-ATPase A & Maize & Baum et al. (2007) \\
\hline \multirow[t]{3}{*}{2} & \multirow[t]{3}{*}{ Virus resistance } & Rice Dwarf Virus (RDV) & PNS12 & Rice & Shimizu et al. (2009) \\
\hline & & Bean golden mosaic virus (BGMV) & AC1 gene & Bean & Bonfim et al. (2007) \\
\hline & & BYDV (Barley Yellow Dwarf Virus) & BYDV-PAV & Barley & Wang et al. (2000) \\
\hline \multirow[t]{3}{*}{3} & \multirow[t]{3}{*}{ Nematode resistance } & Meloidogyne incognita & splicing factor and integrase & Tobacco & Yadav et al. (2006) \\
\hline & & Meloidogyne & $16 \mathrm{D} 10$ & Arabidopsis & Huang et al. (2006) \\
\hline & & Meloidogyne javanica & Tis 11 & Tobacco & Fairbairn et al. (2007) \\
\hline 4 & Bacteria resistance & Xanthomonas citri subsp. citri (Xcc) & PDS and CalS1 & Lemon & Enrique et al. (2011) \\
\hline \multirow[t]{3}{*}{5} & \multirow[t]{3}{*}{ Fungus resistance } & Phytophthora infestans & SYR1 & Potato & $\begin{array}{l}\text { Eschen-Lippold et al. } \\
\text { (2012) }\end{array}$ \\
\hline & & $\begin{array}{l}\text { Phytophthora parasitica var. } \\
\text { nicotianae }\end{array}$ & GST & Tobacco & $\begin{array}{l}\text { Hernández et al. } \\
\text { (2009) }\end{array}$ \\
\hline & & Blumeria graminis f. sp. tritici & MLO & Wheat & Riechen (2007) \\
\hline
\end{tabular}


Table 6 The gene targeted for RNAi-mediated crop improvement

\begin{tabular}{|c|c|c|c|c|c|}
\hline S. no. & Crop improvement & Traits improved & Gene targeted & Plant used & References \\
\hline \multirow[t]{13}{*}{1} & \multirow[t]{13}{*}{ Biofortification } & $\beta$-Carotene and lycopene & NCED1 & Tomato & Sun et al. (2012) \\
\hline & & Carotenoid & $\varepsilon-\mathrm{CYC}$ & Brassica napus & Yu et al. (2007) \\
\hline & & Carotenoid and flavonoid & DET 1 & Tomato & Davuluri et al. (2005) \\
\hline & & $\begin{array}{l}\text { Carotenoid with decreased } \\
\text { sinapate esters }\end{array}$ & DET1 & Brassica napus & Wei et al. (2009) \\
\hline & & $\beta$-Carotene and lutein & $\mathrm{BCH}$ & Potato & Eck et al. (2007) \\
\hline & & \multirow[t]{2}{*}{ Starch } & AtGWD & Maize & Weise et al. (2012) \\
\hline & & & AtGWD and AtSEX4 & Arabidopsis & Weise et al. (2012) \\
\hline & & \multirow[t]{2}{*}{ Lysine } & ZLKR and SDH & Maize & Houmard et al. (2007) \\
\hline & & & Maize zein storage protein & Maize & Segal et al. (2003) \\
\hline & & \multirow[t]{2}{*}{ Amylose } & SBE IIa and SBE IIb & Wheat & Regina et al. (2006) \\
\hline & & & SBE IIa and SBE IIb & Barley & Regina et al. (2010) \\
\hline & & Stearic- and oleic- fatty acids & $\begin{array}{l}\text { Stearoyl-acyl-carrier protein } \\
\Delta 9 \text {-desaturase and oleoyl- } \\
\text { phosphatidylcholine } \omega 6- \\
\text { desaturase }\end{array}$ & Cotton & Liu et al. (2002) \\
\hline & & Vitamin C & APX & Tomato & Zhang et al. (2011) \\
\hline \multirow[t]{3}{*}{2} & \multirow[t]{3}{*}{ Bio-elimination } & Caffeine & CaMXMT 1 & Coffea canephora & Ogita et al. (2003) \\
\hline & & Cadmium & PCS & Rice & Li et al. (2007) \\
\hline & & Morphine & Codeine Reductase (COR) & $\begin{array}{l}\text { Papaver somniferum } \\
\text { (Opium poppy) }\end{array}$ & Allen et al. (2004) \\
\hline \multirow[t]{8}{*}{3} & \multirow[t]{8}{*}{ Altered phenotype } & Flower colour: blue to white & CHS & \multicolumn{2}{|c|}{$\begin{array}{l}\text { Torenia hybrida cv. Sum-Fukusaki et al. (2004) } \\
\text { merwave Blue }\end{array}$} \\
\hline & & Scent profile modification & PhBSMT & Petunia & Underwood et al. (2005) \\
\hline & & \multirow[t]{2}{*}{ Parthenocarpy } & AUCSIA & Tomato & Molesini et al. (2009) \\
\hline & & & CHS & Tomato & Schijlen et al. (2007) \\
\hline & & \multirow[t]{3}{*}{ Male sterility } & TA29 & Tobacco & $\begin{array}{l}\text { Nawaz-ul-Rehman et al. } \\
\text { (2007) }\end{array}$ \\
\hline & & & GEN-L & Rice & Moritoh et al. (2005) \\
\hline & & & BCP1 & Arabidopsis thaliana & Tehseen et al. (2010) \\
\hline & & Fertility restored & orfH522 & Tobacco (male sterile) & $\begin{array}{l}\text { Nizampatnam and Kumar } \\
\text { (2011) }\end{array}$ \\
\hline
\end{tabular}

in crop plants (Hollomon 2012). However, further research is needed to explore the novel strategies amounting to efficient and durable gene silencing. Numerous papers suggest the efficacy of RNAi for better control over the parasitic weeds, virus, bacteria, fungi, nematodes and insects (Table 6).

\section{Parasitic weeds resistance}

Plant parasitic weeds are widely distributed in and around crop fields of many countries, leading to enormous loss of agricultural yield. There are many conventional methods for its control but with several limitations, so there is a need to develop a biotechnological tool to control the parasitic weeds.

Recently, some researchers have reported the application of RNAi technology to develop weed-resistant plant varieties. Aly et al. (2009) have produced transgenic tomato plants bearing M6PR dsRNA-expression cassette. They found that the level of endogenous M6PR mRNA in the tubercles and underground shoots of Orobanche aegyptiaca grown on transgenic tomato plants was reduced by $60-80 \%$ with a significant decrease in mannitol level and a significant increase in the percentage of dead $O$. aegyptiaca tubercles. A parasitic weed-resistant variety of maize was developed using hpRNA-mediated RNAi resistant to Striga asiatica L. (de Framond et al. 2007; Yoder et al. 2009).

\section{Insect and nematode resistance}

Insect pests cost billions of dollars in the form of crop losses and insecticides. Still farmers face an ever-present threat of insecticide resistance, fuelling a continual search for alternative pest-control strategies (Ferry et al. 2006; Gordon and Waterhouse 2007). 
Annually crop loss of worth about US $\$ 125$ billion was reported by unmanageable phytoparasitic nematodes. Gheysen and Vanholme (2007) demonstrated that dsRNA expression in a host plant against housekeeping or parasitism genes in the root-knot nematode results in nematoderesistant plants.

The differentiation of syncytium (plant root organ) is induced by plant-parasitic cyst nematodes for source of nourishment. Syncytium is formed through re-differentiation and fusion of root cells in large number. Hewezi et al. (2012) reported that miR396 has a role in phase transition in Arabidopsis. Strong down-regulation of miR396 in cells giving rise to the syncytium coincides with the initiation of syncytial formation phase and up-regulation of miR396 in the developed syncytium marks the beginning of maintenance phase, when no new cells are incorporated into the syncytium. Expression modulations of miR396 and its growth-regulating factor (GRF) target genes resulted in reduced syncytium size and arrested nematode development. This showed miR396 as a key regulator in reprogramming of root cells representing a powerful molecular target for parasitic animal to modulate plant cells into a novel developmental pathway.

Huang et al. (2006) were first to demonstrate resistance to more than one nematode species, targeting a gene involved in parasitism rather than a nematode housekeeping gene. It is likely that recent sequencing of the Meloidogyne hapla genome will reveal new targets for HD-RNAi (Oppermana et al. 2008).

Through host-induced RNAi, Sindhu et al. (2009) targeted all four nematode parasitism genes of sugar beet cyst nematode (Heterodera schachtii), 3B05, 4G06, 8H07 and 10A06, having host $A$. thaliana. They reported that no complete resistance was observed, but it led to 23-64\% reduction in the number of mature nematode females in different RNAi lines.

Ibrahim et al. (2011) targeted four different genes for RNAi constructs. The genes have high similarity with Heterodera glycines (essential soybean cyst nematode) and $C$. elegans to determine their efficacy to reduce galls formed by Meloidogyne incognita in soybean roots. Of the four, two constructs targeting the genes encoding tyrosine phosphatase (TP) and mitochondrial stress-70 protein precursor (MSP) were able to reduce gall formation by 92 and $94.7 \%$, respectively.

\section{Virus resistance}

Among different strategies to combat virus infections in plants, pathogen-derived resistance (PDR) is the most powerful approach. The application of the PDR concept has helped to engineer virus-resistant plants (Simón-Mateo and García 2011). There is one more strategy that targets multiple regions of a viral gene showing a broad-spectrum resistance against tospoviruses in tomato plants (Bucher et al. 2006). This strategy is most effective and is based upon the use of a miRNA construct that expresses multiple artificial miRNAs (amiRNAs) targeting multiple regions of a viral gene.

Impact of RNAi, targeting the coat protein $(\mathrm{CP})$ gene of viruses is found to be quite effective in inducing resistance to the plant against viruses. There are many viral coat protein targeting RNAi-modified virus-resistant plants such as Beet Necrotic Yellow Vein Virus (BNYVV)-resistant tobacco (Andika et al. 2005), Potato Virus Y (PVY)-resistant potato (Missiou et al. 2004), Papaya Ring Spot Virus type W (PRSV-W)-resistant Cucumis melo L. var. cantalupensis cv. Sun Lady (Krubphachaya et al. 2007), Plum Pox virus (PPV)-resistant Nicotiana benthamiana and Prunus domestica (Hily et al. 2007) and Cucumber Green Mottle Mosaic Virus (CGMMV)-resistant $N$. benthamiana (Kamachi et al. 2007).

Pradeep et al. (2012) reported that the introduction of inverted repeats of the CP gene of Tobacco Streak Virus (TSV) may be an effective and reliable strategy for developing economically important crops with resistance to TSV. Zhou et al. (2012) have created an RNAi construct containing CP gene and disease-specific protein gene sequences from Rice Stripe Virus. Two susceptible japonica varieties, Suyunuo and Guanglingxiangjing, were transformed by RNAi construct to develop resistance against Rice Stripe Disease. It was found that the homozygous progeny of rice plants in the T5 and T7 generations containing RNAi constructs, after self-fertilization were strongly resistant to viral infection without any morphological and developmental differences.

RNAi-mediated silencing of African cassava mosaic virus (ACMV) resulted in a $99 \%$ reduction in Rep transcripts and a $66 \%$ reduction in viral DNA (Vanitharani et al. 2003). Only closely related strain of ACMV can be silenced by siRNA approach. In plant viruses, more than 40 viral suppressors have been identified (Ruiz-Ferrer and Voinnet 2007). Patil et al. (2011) first demonstrated RNAimediated resistance to Cassava Brown Streak Disease (CBSD) in cassava (M. esculenta) and protection against very distant isolates of causative organism (more than $25 \%$ in nucleotide sequence) belonging to two different species: Cassava Brown Streak Virus (CBSV) and Cassava Brown Streak Uganda Virus (CBSUV). Today, CBSD is considered as the leading risk to cassava cultivation in East Africa.

Using black gram (Vigna mungo) as a study system, Pooggin et al. (2003) have discovered that the DNA of a replicating virus can also be a target of RNAi. They have observed recovery of Vigna mungo from MYMIV (Mungbean Yellow Mosaic India Virus) infection by silencing the gene associated with bidirectional promoter through RNAi approach. 
Bonfim et al. (2007) have generated geminivirus-resistant BGMV-resistant common bean using RNAi method. Aragão and Faria (2009) have also presented data on the generation of two transgenic common bean (Phaseolus vulgaris) lines.

There are many other transgenic plants with enhanced defence by RNAi-mediated gene silencing, such as Tomato Yellow Leaf Curl Virus (TYLC)-resistant tomato (Fuentes et al. 2006), Rice Tungro Bacilliform Virus (RTBV)resistant rice (Tyagi et al. 2008) and Citrus Tristeza Virus (CTV)-resistant mexican lime (López et al. 2010). Schwind et al. (2009) have even shown that using hpRNA construct in Solanum lycopersicum (tomato) against Potato Spindle Tuber Viroid (PSTVd) produce PSTVd-resistant tomato plant varieties.

\section{Bacterial resistance}

Bacterial diseases are one of the biggest challenges in crop field such as tomato, soybean and banana. The bacterial diseases spread very fast and become difficult to control, hence prevention is the only way to avoid bacterial infections. Employing RNAi for enhancing bacterial resistance on experimental plant $A$. thaliana has shown good results.

Escobar et al. (2001) showed that silencing of two bacterial genes (iaaM and ipt) could decrease the production of crown gall tumours (Agrobacterium tumefaciens) to nearly zero in Arabidopsis (Dunoyer et al. 2006), suggesting that resistance to crown gall disease could be engineered in trees and ornamental plants.

\section{Fungal resistance}

Research findings show the enhanced defence against fungi in genetically engineered crop plants based on RNAi. In 2010, Xin et al. reported that 24 miRNAs were responsive to powdery mildew infection caused by the obligate biotrophic fungus Blumeria graminis f. sp. tritici. and further predicted 149 target genes which were potentially regulated by the novel wheat miRNA. More examples are summarized in Table 5.

\section{Abiotic stress tolerance}

The application of transgenesis in crop plants was initially aimed to provide protection against pests and tolerance to herbicides (Shewry et al. 2008). Many plant miRNAs play critical roles in nutrient homeostasis, developmental processes, abiotic stresses and pathogen responses (Xin et al. 2010). The miRNA plays important regulatory roles in development and stress response in plants by negatively affecting post-transcriptional gene expression. Identification of miRNAs at the global genome-level by high-throughput sequencing is essential to functionally characterize miRNAs in plants (Wang et al. 2011b). Extensive studies of miRNAs have been performed in model plants such as rice, A. thaliana and other plants. Wang et al. (2011a) investigated about miRNAs involved in the very early stage during seed germination and reported that miRNA-mediated regulation of gene expression is present in maize imbibed seed.

Chen et al. (2012) provided valuable information of miRNAs in $\mathrm{Al}^{3+}$ toxicity and tolerance. They found that 18 miRNAs were providing response in $4 \mathrm{~h}$ of $\mathrm{Al}^{3+}$ treatment, 4 miRNAs belonging to 4 families were found to show response at both $4 \mathrm{~h}$ and $24 \mathrm{~h}$ of $\mathrm{Al}^{3+}$ treatment. The miR390 was down-regulated in response to $24 \mathrm{~h} \mathrm{Al}^{3+}$ treatment and considered as the late responsive miRNAs. Only miR390 is known to regulate auxin response factor which is responsible for the lateral root development (Marin et al. 2010; Yoon et al. 2010).

Wang et al. (2011b) identified drought-responsive miRNAs in a legume model plant, Medicago truncatula. They reported that 22 members of 4 miRNA families were upregulated and 10 members of 6 miRNA families were down-regulated in response to drought stress. Out of 29 new miRNAs/new members of known miRNA families, 8 miRNAs were responsive to drought stress with both 4 miRNAs being up-regulated and down-regulated, respectively. The known and predicted targets of the droughtresponsive miRNAs were found to be involved in diverse cellular processes in plants, including development, transcription, protein degradation, detoxification, nutrient status and cross adaptation.

Sunkar and Zhu (2004) described the role of miRNAs in response to abiotic stresses. The Arabidopsis seedlings were exposed to different abiotic stresses such as drought, cold, salinity, and oxidative stress. It was observed that miR393 was strongly up-regulated by cold, dehydration, high salinity and abscisic acid (ABA) treatments. In addition, by exposing Arabidopsis to different abiotic stress of varying degrees, miR319c, miR389a, miR397b and miR402 were also found to be regulated. In 2010, Xin et al. reported that 12 miRNAs in wheat (Triticum aestivum L.) were responsive to heat stress. In another report, stress-related miRNAs has been identified in rice ( $O$. sativa $\mathrm{L}$. ssp. Japonica $\mathrm{cv}$ 9522) seedlings exposed to abiotic stresses (cold, dehydration, salinity and abscisic acid) as well as wild type (Jian et al. 2010). In addition, several stress-related miRNAs have been discovered in rice and only two miR393 and miR169g have been found to be related to abiotic stress; both were up-regulated by dehydration (Zhao et al. 2007).

Under stress conditions, miR393 is known for its contribution to the anti-bacterial resistance and down regulation of auxin signalling and seedling growth by inhibiting the expression of TIR1 (Vierstra 2003; Jones-Rhoades 
and Bartel 2004; Navarro et al. 2006). Moreover, it was reported that miR159 responds to hormone signalling and dehydration responses in Arabidopsis (Achard et al. 2004; Reyes and Chua 2007).

Recently, Zhang et al. (2012b) found that miR156, miR157, miR166 and miR172 have different expression levels between the juvenile and adult phases of precocious trifoliate orange (Poncirus trifoliata L. Raf.). They also reported that miR156 declined from juvenile to adult stage, whereas miR172 increased during this same period. Whereas the over-expression of miR172 accelerates flowering in Arabidopsis (Chen 2004) and exhibits a similar temporal expression pattern in maize where it targets Glossy 15 , a gene responsible for expression of juvenile epidermal traits (Lauter et al. 2005), the over expression of miR156 delays flowering and prolongs the expression of juvenile vegetative traits in Arabidopsis and maize (Wu and Poethig 2006; Chuck et al. 2007a, b). Thus the expression pattern of miR156 and miR172 is found to be inversely related.

$\mathrm{Hu}$ et al. (2009) showed that the expression of rice histone deacetylases genes display specific expression patterns and divergent developmental functions compared with closely related homologs in Arabidopsis and most of them are responsive to drought or salt stresses.

Hwang et al. (2011) identified drought stress-responsive miR171 family members (named miR171a, miR171b and miR171c) in potato plants, Solanum tuberosum. In waterdeficit condition, Trindade et al. (2010) identified several conserved miRNAs having differential expression in $M$. truncatula plants as miR169 is down-regulated in roots, whereas $\mathrm{miR} 398 \mathrm{a} / \mathrm{b}$ and miR408 are strongly up-regulated in both shoots and roots. The RNAi-suppression of farnesyl transferase genes FTA or FTB, in canola leads to decreased stomatal conductance and thereby transpiration resulting in higher yields in a 3-year field trial (Wang 2005, 2009).

In response to the drought stress, 22 members in 4 miRNA families (miR399, miR2089, miR2111 and miR2118) were up-regulated whereas, 10 members from 6 miRNA families (miR164, miR169, miR171, miR396, miR398 and miR1510) were down-regulated (Wang et al. 2011b). miR399 and miR2111 have also been reported to be up-regulated by abiotic stresses such as phosphate starvation (Bari et al. 2006; Pant et al. 2009). PvPHR1 is supposed to be positive regulator of genes implicated in transport, mobilization and homeostasis of phosphorus. Valdés-López et al. (2008) demonstrated that miRNA399 of P. vulgaris (PvmiR399) is an essential component of the PvPHR1 signalling pathway in common bean $(P$. vulgaris L.). Jones-Rhoades and Bartel (2004) have indicated that miR395 and miR399 are up-regulated when plants suffer from sulphur and phosphate starvation in Arabidopsis.

Leguminous plants are characterized by their ability to develop nitrogen-fixing nodules via an interaction with symbiotic bacteria. Li et al. (2008b) found that silencing of Asnodf32 delayed root nodule and bacteroid senescence with enlarged nodules and extended period for active nitrogen fixation. Asnodf32, which encodes a nodule-specific cysteine proteinase in Astragalus sinicus, is silenced by Agrobacterium rhizogenes-mediated RNAi. Further, Laporte et al. (2010) noted that MtSNARP2-silenced transgenic roots of $M$. truncatula showed aberrant early senescent nodules where differentiated bacteroids degenerate rapidly. Hence, a functional symbiotic interaction may be regulated through secreted RNA-binding peptides.

\section{Future perspective}

The global demand for food is likely to increase with the continuing population growth and consumption (Godfray et al. 2010). In the twenty-first century, the challenge for agriculture will be the improvement of crop production in a sustainable manner (Molesini et al. 2012). According to Godfray et al. (2010), the world is capable of producing more food and can ensure that it is used more efficiently by just employing genetic engineering and metabolic engineering to develop high-yielding crop varieties.

The biomolecules such as carbohydrate, lignin and lipid are well known for their potential to produce bioactive molecules. Carbohydrates and lignin can lead to chemical intermediates such as levulinic acid, vanillin and many other aromatic molecules for the synthesis of pharmaceutical products (Cherubini 2010); while lipids can be used to produce beneficial polyunsaturated fatty acids such as omega-3 (Octave and Thomas 2009). Over the years, several biotechnological techniques have been adopted for enhancing the bioactive molecules in medicinal plants (Khan et al. 2011a, b) like Liquidambar styraciflua tree, which produces shikimic acid, a key intermediate for the antiviral drug Tamiflu (Martin et al. 2010). Lim and Bowles (2012) reviewed the use of plant system to produce small bioactive molecules for health and nutrition; sweetener, flavour and fragrance; and pesticide and insect repellent. Taxol (a produce from Taxus brevifolia) is a mitotic inhibitor, used in the treatment of breast cancer, lung cancer and ovarian cancer. Similarly, diosgenine (Dioscorea deltoidea and Trigonella foenum graecum) inhibits migration and invasion of human prostate cancer PC-3 cells by reducing matrix metalloproteinases expression (Chen et al. 2011). It is also used for the commercial synthesis of cortisone, pregnenolone, progesterone, and other steroid products.

Metabolic engineering can be useful to facilitate synthesis and production of commercially valuable plant products such as drugs, pigments, fragrances, volatile oils and flavours (Table 7) on large scale. RNAi can be utilized with novelty for lowering the enzyme activities that will change the 
Table 7 RNAi could be employed in future as a tool of metabolic engineering for synthesis and production of commercially valuable plant products

\begin{tabular}{|c|c|c|}
\hline RNAi may enhance & Products & Source plant \\
\hline \multirow{6}{*}{$\begin{array}{l}\text { Production of important } \\
\text { natural pharmaceutical } \\
\text { compounds }\end{array}$} & Codeine (Alkaloid) & Papaver sominifera \\
\hline & Quinine (Alkaloid) & Cinchona ledgeriana \\
\hline & Vincristine (Alkaloid) & Catharanthus roseus \\
\hline & Scopolamine (Alkaloid) & Dhatura stramonium \\
\hline & Taxol & Taxus brevifolia \\
\hline & Diosgenine (steroid sapogenen) & $\begin{array}{l}\text { Dioscorea deltoidea and } \\
\text { Trigonella foenum graecum }\end{array}$ \\
\hline \multirow{3}{*}{$\begin{array}{l}\text { Biosynthesis of } \\
\text { scents in flowers }\end{array}$} & Rose & Rosa species \\
\hline & Jasmine & Tabernaemontana divaricata \\
\hline & Lavender & Lavandula Angustifolia \\
\hline \multirow[t]{3}{*}{$\begin{array}{l}\text { Biosynthesis of } \\
\text { flavouring agents }\end{array}$} & Vanillin & $\begin{array}{l}\text { Vanilla planifolia, V. pompon and } V \text {. } \\
\text { tahitiensis }\end{array}$ \\
\hline & Strawberry & Fragaria $\times$ ananassa \\
\hline & Menthol, peppermint or mint & $\begin{array}{l}\text { Mentha arvensis, } M \text {. canadensis and } \\
\text { M. piperita }\end{array}$ \\
\hline \multirow{2}{*}{$\begin{array}{l}\text { Increased number } \\
\text { of floral parts }\end{array}$} & Stigma (Saffron) & Crocus sativus \\
\hline & Petals & Rosa species and Calendula officinalis \\
\hline
\end{tabular}

biochemical reactions leading to formation of desired products instead of unwanted/toxic compounds. RNAi may help to improve the nutraceutical potential of a plant and/its products by enhancing the content of useful amino acids, fatty acids, fibre or by getting rid of allergenic/toxic compounds (Small 2007; Vaucheret 2006; Martino-Catt and Sachs 2008; Newell-McGloughlin 2008). Khan et al. (2012) reported that RNAi is a potential technique being used for the production of medicinal plants with potential traits for a particular marker compound which is needed for eradication of diseases.

The potential digestion of cell wall material by rumen bacteria has been hindered by cell wall lignifications. Total dry matter digestibility has been increased by the traditional breeders rather than cell wall digestibility, resulting in minimal reduction in cell wall lignification. Transgenic approaches down-regulating the genes for enzymes like cinnamate 4-hydroxylase $(\mathrm{C} 4 \mathrm{H})$, hydroxycinnamoyl CoA-shikimate/quinate transferase (HCT), coumarate 3-hydroxylase $(\mathrm{C} 3 \mathrm{H})$, caffeoyl-CoA-3-O-methyltransferase (CCoAOMT), cinnamoyl CoA reductase (CCR), ferulate 5-hydroxylase (F5H), caffeic acid-3-O-methyltransferase (COMT) and cinnamyl alcohol dehydrogenase (CAD) involved in monolignol synthesis have produced plants with reduced lignin content and improved cell wall digestibility. If the targeted gene is a housekeeper, it should be partially silenced by RNAi with gene-specific expression to maintain the cell wall strength.

Not only this, soon RNAi will prove its potential for inhibition of photorespiration to enhance the productivity of $\mathrm{C}_{3}$ plants. This knockdown technology may be useful in inducing early flowering, delayed ripening, delayed senescence, breaking dormancy, stress-free plants, overcoming self-sterility, etc.
Recently there are artificial restriction enzymes designed to effectively alter any gene in an organism. These are alternative to gene silencing and have enough future scope. Curtin et al. (2012) has mentioned three sequence-specific nuclease systems used for crop plants. These are zinc finger nucleases (ZFNs), transcription activator-like effector nucleases (TALENs), and LAGLIDADG homing endonucleases (LHEs), also termed "meganucleases". Generally ZFNs and TALENs cause programmable genetic modifications by inducing breaks in the double strands of DNA. Recently, Gaj et al. (2013) has showed the therapeutic potential of ZFNs and TALENs including the emergence of clustered regulatory interspaced short palindromic repeat (CRISPR)/Cas-based RNA-guided DNA endonucleases. Xanthomonas infects plant cells and delivers a cassette of proteins called transcriptional activator-like effectors (TALEs), which modifies the host's transcriptome by binding to specific DNA sequences. TALENs are the fusion of TALEs (programmable DNA binding domain) and FokI (cleavage domain) enabling the programmable, efficient and precise site-specific RNA-guided DNA nuclease to introduce double-strand breaks (DSBs) for targeted genome modification. TALEN have been used in plants like A. thaliana (Cermak et al. 2011), tobacco (Mahfouz et al. 2011) and rice (Li et al. 2012).

\section{Conclusion}

Malnutrition is a major problem especially in developing countries (WHO 2000). Chronic food deficits affect about 792 million people in the world (FAO 2000) including $20 \%$ of the population in developing countries. To ensure 
a healthy diet for healthy world, there is a necessity to develop bio-fortified cereals, fruits and vegetables through enrichment with nutritionally essential elements and compounds such as essential minerals, antioxidants, vitamins, fatty acids and amino acids.

One of the most important agronomical traits that should be developed in crop plants is the stress (biotic and abiotic) tolerance. So, there is a need to develop plant varieties that will tolerate phytopathogens and pests, along with changing environmental conditions like extreme temperatures, flood, and drought, oxidative stress and changes in soil compositions (heavy metal accumulation, salinity, decreasing fertility, etc.). These plant varieties will be necessary for food security to feed the increasing population. RNAibased researches have proved its potential in crop improvement to overcome the problem of food security, malnutrition and famine.

Rigorous researches have been designed for finding small non-coding regulatory RNAs and reveal their biogenesis and effect on gene suppression; still some facts regarding complexity of RNAi pathway and its components has to be explained. However, the applications of research related with small non-coding RNAs is creating milestone for agricultural improvement, thereby improving the way of life.

RNAi has developed many novel crops such as nicotinefree tobacco, decaffeinated coffee, nutrient fortified and hypoallergenic crops. The genetically engineered Arctic apples are near close to receive US approval. The apples were produced by RNAi suppression of PPO (polyphenol oxidase) gene making apple varieties that will not undergo browning after being sliced. PPO-silenced apples are unable to convert chlorogenic acid into quinone product.

Now, RNAi can be used in production of blue rose by suppressing cyanidin genes; generating low lignin content jute varieties for high-quality paper; healthier oil production by suppressing the enzyme that converts oleic acid into a different fatty acid; regulating flowering time in crops. It can be a boon for production of BBrMV-resistant banana varieties against Banana Bract Mosaic Virus (BBrMV), a challenge for banana population in Southeast Asia and India (Rodoni and Dale 1999).

One of the major concerns about selection of transformed plant is the use of antibiotic resistance markers. The antibiotic resistance gene may evoke environmental concern as it may lead to antibiotic resistant microbes by horizontal gene transfer. Alternative ways such as the use of pmi (phosphomannose isomerase) gene, $w b c 19$ (ABC transporter) gene, ak (aspartate kinase) gene and dhps (dihydrodipicolinate synthase) gene leads to positive selection (Jaiwal et al. 2002). However, the NptII gene has earned "generally regarded as safe" status from the USFDA (1993) as it can be used in vectors in genetic engineering for crop development producing safe food. NptII protein imparts kanamycin tolerance and used as a tool to select transformed plants.

The phenomenon of RNAi cause transcriptional gene silencing by chromatin modification leading to heterochromatin formation. These modifications might become hereditary and may cause potential adverse effects leading to biosafety risks. The crop plants developed through RNAi should undergo risk assessment related to food safety and environment protection. So, there is a need to tailor customize vectors according to the necessity of crop improvement.

Nevertheless, RNAi can be highly effective for functional genomics and biotechnology of perennial plants $(\mathrm{Li}$ et al. 2008a). To meet the global demand for food, fibre and fuel the production of improved crops are needed (Chapotin and Wolt 2007), which will be provided with the advances in RNAi technology. There are several opportunities for the applications of RNAi in crop science for its improvement such as stress tolerance and enhanced nutritional level. Thus, there is huge potential of RNAi to improve the agricultural yield significantly.

Acknowledgments The Author gratefully acknowledges Birla Institute of Technology, Mesra (Ranchi) for providing fellowship to S.S. and UGC BSR (Start-up Grant No. 20-3 (19)/2012(BSR) New Delhi for financial support to carry out the research.

\section{References}

Aalto AP, Pasquinelli AE (2012) Small non-coding RNAs mounting a silent revolution in gene expression. Curr Opin Cell Biol 24:1-8

Achard P, Herr A, Baulcombe DC, Harberd NP (2004) Modulation of floral development by gibberellin-regulated microRNA. Development. 131:3357-3365

Allen RS, Millgate AG, Chitty JA, Thisleton J, Miller JAC, Fist AJ, Gerlach WL, Larkin PJ (2004) RNAi mediated replacement of morphine with the non-narcotic alkaloid reticuline in opium poppy. Nat Biotechnol 22:1559-1566

Aly R, Cholakh H, Joel DM, Leibman D, Steinitz B, Zelcer A, Naglis A, Yarden O, Gal-On A (2009) Gene silencing of mannose 6-phosphate reductase in the parasitic weed Orobanche aegyptiaca through the production of homologous dsRNA sequences in the host plant. Plant Biotechnol J 7:487-498

Andika IB, Kondo H, Tamada T (2005) Evidence that RNA silencingmediated resistance to beet necrotic yellow vein virus is less effective in roots than in leaves. Mol Plant-Microbe Interact. 18:194-204

Angaji SA, Hedayati SS, Hosein poor R, Samad poor S, Shiravi S, Madani S (2010) Application of RNA interference in plants. Plant Omics J 3:77-84

Aragão FJL, Faria JC (2009) First transgenic geminivirus-resistant plant in the field. Nat Biotechnol 27:1086-1088

Aukerman MJ, Sakai H (2003) Regulation of flowering time and floral organ identity by a microRNA and its APETALA2-like target genes. Plant Cell 15:2730-2741

Babiarz JE, Ruby JG, Wang Y, Bartel DP, Blelloch R (2008) Mouse ES cells express endogenous shRNAs, siRNAs, and other Microprocessor-independent. Dicer-dependent small RNAs. Genes Dev. 22:2773-2785 
Bari R, Pant BD, Stitt M, Scheible WR (2006) PHO2, microRNA399, and PHR1 define a phosphate-signaling pathway in plants. Plant Physiol 141:988-999

Baum JA, Bogaert T, Clinton W, Heck GR, Feldmann P, Ilagan O, Johnson S, Plaetinck G, Munyikwa T, Pleau M, Vaughn T, Roberts J (2007) Control of coleopteran insect pests through RNA interference. Nat Biotechnol 25:1322-1326

Bernstein E, Caudy AA, Hammond SM, Hannon GJ (2001) Role for a bidentate ribonuclease in the initiation step of RNA interference. Nature 409:363-366

Billy E, Brondani V, Zhang H, Muller U, Filipowicz W (2001) Specific interference with gene expression induced by long, doublestranded RNA in mouse embryonal teratocarcinoma cell lines. Proc Natl Acad Sci USA 98:14428-14433

Bonfim K, Faria JC, Nogueira EO, Mendes EA, Aragão FJ (2007) RNAi-mediated resistance to Bean golden mosaic virus in genetically engineered common bean (Phaseolus vulgaris). Mol Plant-Microbe Interact. 20:717-726

Brown ME, Funk CC (2008) Climate: food security under climate change. Science 319:580-581

Bucher E, Lohius D, van Poppel PM, Geerts-Dimitriadou C, Goldbach R, Prins M (2006) Multiple virus resistance at a high frequency using a single transgene construct. J Gen Virol 87:697-701

Burkhart KB, Guang S, Buckley BA, Wong L, Bochner AF, Kennedy $S$ (2011) A pre-mRNA-associating factor links endogenous siRNAs to chromatin regulation. PLoS Genet 7:e1002249

Byzova M, Verduyn C, De Brouwer D, De Block M (2004) Transforming petals into sepaloid organs in Arabidopsis and oilseed rape: implementation of the hairpin RNA-mediated gene silencing technology in an organ-specific manner. Planta 218:379-387

Cartolano M, Castillo R, Efremova N, Kuckenberg M, Zethof J, Gerats T, Schwarz-Sommer Z, Vandenbussche M (2007) A conserved microRNA module exerts homeotic control over Petunia hybrida and Antirrhinum majus floral organ identity. Nat Genet 39:901-905

Cermak T, Doyle EL, Christian M, Wang L, Zhang Y, Schmidt C, Baller JA, Somia NV, Bogdanove AJ, Voytas DF (2011) Efficient design and assembly of custom TALEN and other TAL effector based constructs for DNA targeting. Nucleic Acids Res. doi:10.1093/nar/gkr218

Chapotin SM, Wolt JD (2007) Genetically modified crops for the bioeconomy: meeting public and regulatory expectations. Transgenic Res 16:675-688

Chen X (2004) A microRNA as a translational repressor of APETALA2 in Arabidopsis flower development. Science 303:2022-2025

Chen S, Hajirezaei MR, Zanor MI, Hornyik C, Debast S, Lacomme C, Fernie AR, Sonnewald U, Börnke F (2008) RNA interference-mediated repression of sucrose-phosphatase in transgenic potato tubers (Solanum tuberosum) strongly affects the hexoseto-sucrose ratio upon cold storage with only minor effects on total soluble carbohydrate accumulation. Plant Cell Environ 31:165-176

Chen P, Shih Y, Huang H, Cheng H (2011) Diosgenin, a steroidal saponin, inhibits migration and invasion of human prostate cancer PC-3 cells by reducing matrix metalloproteinases expression. PLoS ONE. doi:10.1371/journal.pone.0020164

Chen L, Wang T, Zhao M, Tian Q, Zhang WH (2012) Identification of aluminum-responsive microRNAs in Medicago truncatula by genome-wide high-throughput sequencing. Planta 235:375-386

Cherubini F (2010) The biorefinery concept: using biomass instead of oil for producing energy and chemicals. Energy Convers Manage 51:1412-1421
Chuck G, Cigan AM, Saeteurn K, Hake S (2007a) The heterochronic maize mutant Corngrass 1 results from overexpression of a tandem microRNA. Nat Genet 39:544-549

Chuck G, Meeley R, Irish E, Sakai H, Hake S (2007b) The maize tasselseed 4 microRNA controls sex determination and meristem cell fate by targeting Tasselseed6/indeterminate spikelet1. Nat Genet 39:1517-1521

Cigan AM, Unger-Wallace E, Haug-Collet K (2005) Transcriptional gene silencing as a tool for uncovering gene function in maize. Plant J 43:929-940

Curtin SJ, Voytas DF, Stupar RM (2012) Genome engineering of crops with designer nucleases. Plant Genome 5:42-50

Davuluri GR, van Tuinen A, Fraser PD, Manfredonia A, Newman R, Burgess D, Brummell DA, King SR, Palys J, Uhlig J, Bramley PM, Pennings HM, Bowler C (2005) Fruit-specific RNAi-mediated suppression of DET1 enhances carotenoid and flavonoid content in tomatoes. Nat Biotechnol 23:890-895

De Framond A, Rich PJ, McMillan J, Ejeta G (2007) Effects of Striga parasitism of transgenic maize armed with RNAi constructs targeting essential S. asiatica genes. In: Ejeta G, Gressel J (ed) Integrating new technologies for striga control. World Scientific Publishing Co. Singapore press, pp 185-196

De Jong M, Wolters-Arts M, Feron R, Mariani C, Vriezen WH (2009) The Solanum lycopersicum Auxin Response Factor 7 (S1ARF7) regulates auxin signalling during tomato fruit set and development. Plant J 57:160-170

Denna DW (1973) Effect of genetic parthenocarpy and gynoecious flowering habit on fruit production and growth of cucumber, Cucumis sativus L. J Am Soc Hort Sci 98:602-604

Dexter R, Qualley A, Kish CM (2007) Characterization of a petunia acetyltransferase involved in the biosynthesis of the floral volatile isoeugenol. Plant J 49:265-275

Dhankher OP, Rosen BP, McKinney EC, Meagher RB (2006) Hyperaccumulation of arsenic in the shoots of Arabidopsis silenced for arsenate reductase (ACR2). Proc Natl Acad Sci USA 103:5413-5418

Dodo HW, Konan KN, Chen FC, Egnin M, Viquez OM (2008) Alleviating peanut allergy using genetic engineering: the silencing of the immunodominant allergen Ara h 2 leads to its significant reduction and a decrease in peanut allergenicity. Plant Biotechnol J 6:135-145

Dunoyer P, Himber C, Voinnet O (2006) Induction, suppression and requirement of RNA silencing pathways in virulent Agrobacterium tumefaciens infections. Nat Genet 38:258-263

Eady CC, Kamoi T, Kato M, Porter NG, Davis S, Shaw M, Kamoi A, Imai S (2008) Silencing onion lachrymatory factor synthase causes a significant change in the sulfur secondary metabolite profile. Plant Physiol 147:2096-2106

Eck JV, Conlin B, Garvin DF, Mason H, Navarre DA, Brown CR (2007) Enhancing beta-carotene content in potato by RNAimediated silencing of the beta-carotene hydroxylase gene. Am J Potato Res 84:331-342

Elbashir SM, Lendeckel W, Tuschl T (2001) RNA interference is mediated by 21 and 22 nt RNAs. Genes Dev 15:188-200

Ender C, Meister G (2010) Argonaute proteins at a glance. J Cell Sci 123:1819-1823

Enrique R, Siciliano F, Favaro MA, Gerhardt N, Roeschlin R, Rigano L, Sendin L, Castagnaro A, Vojnov A, Marano MR (2011) Novel demonstration of RNAi in citrus reveals importance of citrus callose synthase in defence against Xanthomonas citri subsp. Citri. Plant Biotechnol J 9:394-407

Eschen-Lippold L, Landgraf R, Smolka U, Schulze S, Heilmann M, Heilmann I, Hause G, Rosahl S (2012) Activation of defence against Phytophthora infestans in potato by down-regulation of syntaxin gene expression. New Phytol 193:985-996 
Escobar MA, Civerolo EL, Summerfelt KR, Dandekar AM (2001) RNAi-mediated oncogene silencing confers resistance to crown gall tumorigenesis. Proc Natl Acad Sci USA 98:13437-13442

Fagegaltier D, Bouge AL, Berry B, Poisot E, Sismeiro O, Coppee JY, Theodore L, Voinnet O, Antoniewski C (2009) The endogenous siRNA pathway is involved in heterochromatin formation in Drosophila. Proc Natl Acad Sci USA 106:21258-21263

Fairbairn DJ, Cavallaro AS, Bernard M, Mahalinga-Iyer J, Graham MW, Botella JR (2007) Host-delivered RNAi: an effective strategy to silence genes in plant parasitic nematodes. Planta 226: $1525-1533$

Falavigna A, Soressi GP (1987) Influence of the pat-sha gene on plant and fruit traits in tomato (L. esculentum Mill.). In: Modern trends in tomato genetics and breeding, $\mathrm{p}$ 128. Proceedings of the 10th meeting of the EUCARPIA tomato working group

FAO (2000) The state of food insecurity in the world 2000. FAO, Rome

Ferry N, Edwards MG, Gatehouse J, Capell T, Christou P, Gatehouse AMR (2006) Transgenic plants for insect pest control a forward looking scientific perspective. Transgenic Res 15:13-19

Fire A (1999) RNA-triggered gene silencing. Trends Genet $15: 358-363$

Flores T, Karpova O, Su X, Zeng P, Bilyeu K, Sleper DA, Nguyen HT, Zhang ZJ (2008) Silencing of GmFAD3 gene by siRNA leads to low alpha-linolenic acids (18:3) of fad3-mutant phenotype in soybean [Glycine $\max$ (Merr.)]. Transgenic Res $17: 839-850$

Fuentes A, Ramos PL, Fiallo E, Callard D, Sanchez Y, Peral R, Rodriguez R, Pujol M (2006) Intron-hairpin RNA derived from replication associated protein $\mathrm{C} 1$ gene confers immunity to tomato yellow leaf curl virus infection in transgenic tomato plants. Transgenic Res 15:291-304

Fukusaki E, Kawasaki K, Kajiyama S, An CI, Suzuki K, Tanaka Y, Kobayashi A (2004) Flower color modulations of Torenia hybrida by down regulation of chalcone synthase genes with RNA interference. J Biotechnol 111:229-240

Gaj T, Gersbach CA, Barbas CF (2013) ZFN, TALEN, and CRISPR/Cas-based methods for genome engineering. Trends Biotechnol 31:397-405

Gatehouse JA (2008) Biotechnological prospects for engineering insect-resistant plants. Plant Physiol 146:881-887

Gavilano LB, Coleman NP, Burnley L, Bowman M, Kalengamaliro N, Hayes A, Bush LP, Siminszky B (2006) Genetic engineering of Nicotiana tabacum for reduced nornicotine content. J Agric Food Chem 54:9071-9078

Gheysen G, Vanholme B (2007) RNAi from plants to nematodes. Trends Biotechnol 25:89-92

Gil-Humanes J, Pisto'n F, Hernando A, Alvarez JB, Shewry PR, Barro F (2008) Silencing of g-gliadins by RNA interference (RNAi) in bread wheat. J Cereal Sci 48:565-568

Gil-Humanes J, Pistón F, Rosell CM, Barro F (2012) Significant down-regulation of gamma-gliadins has minor effect on gluten and starch properties of bread wheat. J Cereal Sci. doi:10.1016/j.jcs.2012.02.009

Gilisen LJ, Bolhar ST, Matos CI, Rouwendal GJ, Boone MJ, Krens FA, Zuidmeer L, Leeuwen AV, Akkerdaas J, Hoffmann-Sommergruber K, Knulst AC, Bosch D, de Weg WEV, Ree RV (2005) Silencing of major apple allergen Mal d 1 by using the RNA interference approach. J Allergy Clin Immunol 115:364-369

Godfray HCJ, Beddington JR, Crute IR, Haddad L, Lawrence D, Muir JZ, Pretty J, Robinson S, Thomas SM, Toulmin C (2010) Food security: the challenge of feeding 9 billion people. Science 327:812-818

Gordon KHJ, Waterhouse PM (2007) RNAi for insect-proof plants. Nat Biotechnol 25:1231-1232
Grishok A, Pasquinelli AE, Conte D, Li N, Parrish S, Ha I, Baillie DL, Fire A, Ruvkun G, Mello CC (2001) Mechanisms related to RNA interference regulate expression of the small temporal RNAs that control C. elegans developmental timing. Cell 106:23-34

Hamilton AJ, Baulcombe DC (1999) A species of small antisense RNA in posttranscriptional gene silencing in plants. Science 286:950-952

Hecht SS (1998) Biochemistry, biology and carcinogenicity of tobacco specific N-nitrosamines. Chem Res Toxicol 11:559-603

Hernández I, Chacón O, Rodriguez R, Portieles R, Pujol YLM, Borrás-Hidalgo $\mathrm{O}$ (2009) Black shank resistant tobacco by silencing of glutathione $S$-transferase. Biochem Biophys Res Commun 387:300-304

Hewezi T, Maier TR, Nettleton D, Baum TJ (2012) The Arabidopsis MicroRNA396-GRF1/GRF3 regulatory module acts as a developmental regulator in the reprogramming of root cells during cyst nematode infection. Plant Physiol 159:321-335

Hily JM, Ravelonandro M, Damsteegt V, Basset C, Petri C, Liu Z, Scorza R (2007) Plum pox virus coat protein gene intron-hairpin-RNA (ihpRNA) constructs provide resistance to plum pox virus in Nicotiana bethamiana and Prunus domestica. J Am Soc Hort Sci 132:850-858

Hollomon DW (2012) Do we have the tools to manage resistance in the future? Pest Manage Sci 68:149-154

Houmard NM, Mainville JL, Bonin CP, Huang S, Luethy MH, Malvar TM (2007) High-lysine corn generated by endosperm-specific suppression of lysine catabolism using RNAi. Plant Biotechnol J 5:605-614

Hu Y, Qin F, Huang L, Sun Q, Li C, Zhao Y, Zhou D (2009) Rice histone deacetylase genes display specific expression patterns and developmental functions. Biochem Biophys Res Commun 388:266-271

Huang G, Allen R, Davis EL, Baum TJ, Hussey RS (2006) Engineering broad root-knot resistance in transgenic plants by RNAi silencing of a conserved and essential root-knot nematode parasitism gene. Proc Natl Acad Sci USA 103:14302-14306

Huntzinger E, Izaurralde E (2011) Gene silencing by microRNAs: contributions of translational repression and mRNA decay. Nat Rev Genet 12:99-110

Hüsken A, Baumert A, Milkowski C, Becker HC, Strack D, Möllers C (2005) Resveratrol glucoside (Piceid) synthesis in seeds of transgenic oilseed rape (Brassica napus L.). Theor Appl Genet 111:1553-1562

Hutvagner G, McLachlan J, Pasquinelli AE, Balint E', Tuschl T, Zamore PD (2001) A cellular function for the RNA-interference enzyme Dicer in the maturation of the let-7 small temporal RNA. Science 293:834-838

Hwang EW, Shin SJ, Yu BK, Byun MO, Kwon HB (2011) miR171 family members are involved in drought response in Solanum tuberosum. J Plant Biol 54:43-48

Ibrahim HMM, Alkharouf NW, Meyer SLF, Aly MAM, El-Din AEKYG, Hussein EHA, Matthews BF (2011) Post-transcriptional gene silencing of root-knot nematode in transformed soybean roots. Exp Parasitol 127:90-99

Jaiwal PK, Sahoo L, Singh ND, Singh RP (2002) Strategies to deal with the concern about marker genes in transgenic plants: some environmentally friendly approaches. Curr Sci 83:128-136

Jian X, Zhang L, Li G, Zhang L, Wang X, Cao X, Fang X, Zha FC (2010) Identification of novel stress-regulated microRNAs from Oryza sativa L. Genomics 95:47-50

Jones-Rhoades MW, Bartel DP (2004) Computational identification of plant micro-RNAs and their targets, including a stressinduced miRNA. Mol Cell 14:787-799

Jørgensen K, Bak S, Busk PK, Sørensen C, Olsen CE, PuontiKaerlas J, Moller BL (2005) Cassava plants with a depleted 
cyanogenic glucoside content in leaves and tubers. Plant Physiol 139:363-374

Jung HJG, Samac DA, Sarath G (2012) Modifying crops to increase cell wall digestibility. Plant Sci 185-186:65-77

Kamachi S, Mochizuki A, Nishiguchi M, Tabei Y (2007) Transgenic Nicotiana benthamiana plants resistant to cucumber green mottle mosaic virus based on RNA silencing. Plant Cell Rep 26:1283-1288

Kaminaga Y, Schnepp J, Peel G, Kish CM, Ben-Nissan G, Weis D, Orlova I, Lavie O, Rhode D, Wood K, Porterfield DM, Cooper AJL, Schloss JV, Pichersky E, Vainstein A, Dudareva N (2006) Phenylacetaldehyde synthase from Petunia hybrida is a biofunctional enzyme that catalyzes the efficient coupling of phenylalanine decarboxylation to phenylalanine oxidation. J Biol Chem 281:23357-23366

Kapoor S, Kobayashi A, Takatsuji S (2002) Silencing of the tapetum-specific zinc finger gene TAZl causes premature degeneration of tapetum and pollen abortion in petunia. Plant Cell 14:2353-2367

Ketting RF, Fischer SE, Bernstein E, Sijen T, Hannon GJ, Plasterk RH (2001) Dicer functions in RNA interference and in synthesis of small RNA involved in developmental timing in C. elegans. Genes Dev 15:2654-2659

Khan S, Mirza KJ, Al-Qurainy F, Abdin MZ (2011a) Authentication of the medicinal plant Senna angustifolia by RAPD profiling. Saudi J Biol Sci 18:287-297

Khan S, Mirza KJ, Tyagi MR, Abdin MZ (2011b) Development of RAPD markers for authentication of Ruta graveolens (L) and its adulterant. Med Aromat Plant Sci Biotechnol 5:58-61

Khan S, Al-Qurainy F, Nadeem M (2012) Biotechnological approaches for conservation and improvement of rare and endangered plants of Saudi Arabia. Saudi J Biol Sci 19:1-11

Knight SW, Bass BL (2001) A role for the RNase III enzyme DCR-1 in RNA interference and germ line development in Caenorhabditis elegans. Science 293:2269-2271

Koeduka T, Fridman E, Gang DR, Vassa DG, Jackson BL, Kish CM, Orlova I, Spassova SM, Lewis NG, Noel JP, Baiga TJ, Dudareva N, Pichersky E (2006) Eugenol and isoeugenol, characteristic aromatic constituents of spices, are biosynthesized via reduction of a coniferyl alcohol ester. Proc Natl Acad Sci USA 103:10128-10133

Krubphachaya P, Juříček M, Kertbundit S (2007) Induction of RNAmediated resistance to papaya ring spot virus type W. J Biochem Mol Biol 40:401-411

Kusaba M, Miyahara K, Iida S, Fukuoka H, Takano T, Sassa H, Nishimura M, Nishio T (2003) Low glutelin content 1: a dominant mutation that suppresses the glutelin multigene family via RNA silencing in rice. Plant Cell 15:1455-1467

Laporte P, Satiat-Jeunemaitre B, Velasco I, Csorba T, Van de Velde W, Campalans A, Burgyan J, Arevalo-Rodriguez M, Crespi M (2010) A novel RNA-binding peptide regulates the establishment of the Medicago truncatula-Sinorhizobium meliloti nitrogen-fixing symbiosis. Plant J. 62:24-38

Lauter N, Kampani A, Carlson S, Goebel M, Moose SP (2005) microRNA172 down-regulates glossy 15 to promote vegetative phase change in maize. Proc Natl Acad Sci USA 102:9412-9417

Le L, Lorenz Y, Scheurer S, Fotisch K, Enrique E, Bartra J, Biemelt S, Vieths S, Sonnewald U (2006) Design of tomato fruits with reduced allergenicity by dsRNAi-mediated inhibition of ns-LTP (Lyc e 3) expression. Plant Biotechnol J 4:231-242

Lee RC, Feinbaum RL, Ambros V (1993) The C. elegans heterochronic gene lin-4 encodes small RNAs with antisense complementarity to lin-14. Cell 75:843-854

Lee Y, Kim M, Han J, Yeom KH, Lee S, Baek SH, Kim VN (2004) MicroRNA genes are transcribed by RNA polymerase II. EMBO J 23:4051-4060
Lewis RS, Jack AM, Morris JW, Robert VJM, Gavilano LB, Siminszky B, Bush LP, Hayes AJ, Dewey RE (2008) RNA interference (RNAi)-induced suppression of nicotine demethylase activity reduces levels of a key carcinogen in cured tobacco leaves. Plant Biotechnol J 6:346-354

Li JC, Guo JB, Xu WZ, Ma M (2007) RNA interference-mediated silencing of phytochelatin synthase gene reduces cadmium accumulation in rice seeds. J Int Plant Biol 49:1032-1037

Li J, Brunner AM, Shevchenko O, Meilan R, Ma C, Skinner JS, Strauss SH (2008a) Efficient and stable transgene suppression via RNAi in field-grown poplars. Transgenic Res 17:679-694

Li Y, Zhou L, Li Y, Chen D, Tan X, Lei L, Zhou J (2008b) A nodule-specific plant cysteine proteinase, AsNODF32, is involved in nodule senescence and nitrogen fixation activity of the green manure legume Astragalus sinicus. New Phytol 180:185-192

Li T, Liu B, Spalding MH, Weeks DP, Yang B (2012) High efficiency TALEN-based gene editing produces disease-resistant rice. Nat Biotechnol 30:390-392. doi:10.1038/nbt.2199

Lim EK, Bowles D (2012) Plant production systems for bioactive small molecules. Curr Opin Biotechnol. 23:271-277

Liu Q, Singh PS, Green AG (2002) High-stearic and high-oleic cotton seed oils produced by hairpin RNA-mediated post-transcriptional gene silencing. Plant Physiol 129:1732-1743

Lobell DB, Burke MB, Tebaldi C, Mastrandrea MD, Falcon WP, Naylor RL (2008) Prioritizing climate change adaptation needs for food security in 2030. Science 319:607-610

López C, Cervera M, Fagoaga C, Moreno P, Navarro L, Flores R, Peña L (2010) Accumulation of transgene-derived siRNAs is not sufficient for RNAi-mediated protection against Citrus tristeza virus in transgenic Mexican lime. Mol Plant Pathol 11:33-41

Mahfouz MM, Li L, Shamimuzzaman M, Wibowo A, Fang X, Zhu JK (2011) De novo-engineered transcription activator-like effector (TALE) hybrid nuclease with novel DNA binding specificity creates double-strand breaks. Proc Natl Acad Sci USA 108:2623-2628. doi:10.1073/pnas. 1019533108

Mao YB, Cai WJ, Wang JW, Hong GJ, Tao XY, Wang LJ, Huang YP, Chen XY (2007) Silencing a cotton bollworm P450 monooxygenase gene by plant-mediated RNAi impairs larval tolerance of gossypol. Nat Biotechnol 25:1307-1313

Marin E, Jouannet V, Herz A, Lokerse AS, Weijers D, Vaucheret H, Nussaume L, Crespi MD, Maizel A (2010) miR390, Arabidopsis TAS3 tasiRNAs, and their AUXIN RESPONSE FACTOR targets define an autoregulatory network quantitatively regulating lateral root growth. Plant Cell 22:1104-1117

Martin E, Duke J, Pelkki M, Clausen EC, Carrier DJ (2010) Sweetgum (Liquidambar styraciflua L.): extraction of shikimic acid coupled to dilute acid pretreatment. Appl Biochem Biotechnol 162:1660-1668

Martino-Catt S, Sachs ES (2008) Editors choice series: the next generation of biotech crops. Plant Physiol 147:3-5

McGarry RC, Ayre BG (2012) Manipulating plant architecture with members of the CETS gene family. Plant Sci 188-189:71-81

Meli VS, Ghosh S, Prabha TN, Chakraborty N, Chakraborty S, Datta A (2010) Enhancement of fruit shelf life by suppressing N-glycan processing enzymes. Proc Natl Acad Sci USA 107:2413-2418

Mentewab A, Stewart CN Jr (2005) Overexpression of an Arabidopsis thaliana $\mathrm{ABC}$ transporter confers kanamycin resistance to transgenic plants. Nat Biotechnol 23:1177-1180

Missiou A, Kalantidis K, Boutla A, Tzortzakaki S, Tabler M, Tsagris M (2004) Generation of transgenic potato plants highly resistant to potato virus Y (PVY) through RNA silencing. Mol Breed 14:185-197 
Mittler R, Blumwald E (2010) Genetic engineering for modern agriculture: challenges and perspectives. Annu Rev Plant Biol 61:443-462

Mohamed R, Wang CT, Ma C, Shevchenko O, Dye SJ, Puzey JR, Etherington E, Sheng XY, Meilan R, Strauss SH, Brunner AM (2010) Populus CEN/TFL1 regulates first onset of flowering, axillary meristem identity and dormancy release in Populus. Plant J 62:674-688

Molesini B, Pandolfini T, Rotino GL, Dani V, Spena A (2009) Aucsia gene silencing causes parthenocarpic fruit development in tomato. Plant Physiol 149:534-548

Molesini B, Pii Y, Pandolfini T (2012) Fruit improvement using intragenesis and artificial microRNA. Trends Biotechnol 30:80-88

Moritoh S, Miki D, Akiyama M, Kawahara M, Izawa T, Maki H, Shimamoto K (2005) RNAi-mediated silencing of OsGEN-L (OsGEN-like), a new member of the RAD2/XPG nuclease family, causes male sterility by defect of microspore development in rice. Plant Cell Physiol 46:699-715

Nakatsuka T, Mishiba KI, Kubota A, Abe Y, Yamamura S, Nakamura N, Tanaka Y, Nishihara M (2010) Genetic engineering of novel flower colour by suppression of anthocyanin modification genes in gentian. J Plant Physiol 167:231-237

Navarro L, Dunoyer P, Jay F, Arnold B, Dharmasiri N, Estelle M, Voinnet O, Jones JD (2006) A plant miRNA contributes to antibacterial resistance by repressing auxin signalling. Science 312:436-439

Nawaz-ul-Rehman MS, Mansoor S, Khan AA, Zafar Y, Briddon RW (2007) RNAi-mediated male sterility of tobacco by silencing TA29. Mol Biotechnol 36:159-165

Newell-McGloughlin M (2008) Nutritionally improved agricultural crops. Plant Physiol 147:939-953

Niggeweg R, Michael AJ, Martin C (2004) Engineering plants with increased levels of the antioxidant chlorogenic acid. Nat Biotechnol 22:746-754

Nishihara M, Nakatsuka T, Yamamura S (2005) Flavonoid components and flower color change in transgenic tobacco plants by suppression of chalcone isomerase gene. FEBS Lett 579:6074-6078

Nizampatnam NR, Kumar VD (2011) Intron hairpin and transitive RNAi mediated silencing of orfH522 transcripts restores male fertility in transgenic male sterile tobacco plants expressing orfH522. Plant Mol Biol 76:557-573

Nunes ACS, Giovanni R, Cuneo VF, Amaya-Farfan J, de Capdeville G, Rech EL, Aragao FJL (2006) RNAi-mediated silencing of the myo-inositol-1-phosphate synthase gene (GmMIPS1) in transgenic soybean inhibited seed development and reduced phytate content. Planta 224:125-132

Obembe OO, Popoola JO, Leelavathi S, Reddy SV (2011) Advances in plant molecular farming. Biotechnol Adv 29:210-222

Octave S, Thomas D (2009) Biorefinery: toward an industrial metabolism. Biochimie 91:659-664

Ogita S, Uefuji H, Yamaguchi Y, Koizumi N, Sano H (2003) Producing decaffeinated coffee plants. Nature 423:823

Okamura K, Hagen JW, Duan H, Tyler DM, Lai EC (2007) The mirtron pathway generates microRNA-class regulatory RNAs in Drosophila. Cell 130:89-100

Oppermana CH, Bird DM, Williamson VM, Rokhsar DS, Burke M, Cohn J, Cromer J, Diener S, Gajan J, Graham S, Houfek TD, Liu Q, Mitros T, Schaff J, Schaffer R, Scholl E, Sosinski BR, Thomas VP, Windham E (2008) Sequence and genetic map of Meloidogyne hapla: a compact nematode genome for plant parasitism. Proc Natl Acad Sci USA 105:14802-21480

Orlova I, Marshall-Colón A, Schnepp J, Wood B, Varbanova M, Fridman E, Blakeslee JJ, Peer WA, Murphy AS, Rhodes D, Pichersky E, Dudareva N (2006) Reduction of benzenoid synthesis in petunia flowers reveals multiple pathways to benzoic acid and enhancement in auxin transport. Plant Cell 18:3458-3475

Ossowski S, Schwab R, Weigel D (2008) Gene silencing in plants using artificial microRNAs and other small RNAs. Plant J 53:674-690

Otani M, Hamada T, Katayama K, Kitahara K, Kim SH, Takahata Y, Suganuma T, Shimada T (2007) Inhibition of the gene expression for granule-bound starch synthase I by RNA interference in sweet potato plants. Plant Cell Rep 26:1801-1807

Pandolfini T (2009) Seedless fruit production by hormonal regulation of fruit set. Nutrients 1:168-177

Pant BD, Musialak-Lange M, Nuc P, May P, Buhtz A, Kehr J, Walther D, Scheible WR (2009) Identification of nutrient-responsive Arabidopsis and rapeseed microRNAs by comprehensive real-time polymerase chain reaction profiling and small RNA sequencing. Plant Physiol 150:1541-1555

Pare JM, Hobman TC (2007) Dicer: structure, function and role in RNA-dependent gene-silencing pathways In: Polaina J, MacCabe AP (ed) Industrial enzymes, Springer, Berlin, pp 421-438

Pasquinelli AE, Reinhart BJ, Slack F, Martindale MQ, Kuroda MI, Maller B, Hayward DC, Ball EE, Degnan B, Müller P, Spring J, Srinivasan A, Fishman M, Finnerty J, Corbo J, Levine M, Leahy P, Davidson E, Ruvkun G (2000) Conservation of the sequence and temporal expression of let-7 heterochronic regulatory RNA. Nature 408:86-89

Patil BL, Ogwok E, Wagaba H, Mohammed IU, Yadav JS, Bagewadi B, Taylor NJ, Kreuze JF, Maruthi MN, Alicai T, Fauquet CM (2011) RNAi-mediated resistance to diverse isolates belonging to two virus species involved in Cassava brown streak disease. Mol Plant Pathol 12:31-41

Pooggin M, Shivaprasad PV, Veluthambi K, Hohn T (2003) RNAi targeting of DNA virus in plants. Nat Biotechnol 21:131-132

Pradeep K, Satya VK, Selvapriya M, Vijayasamundeeswari A, Ladhalakshmi D, Paranidharan V, Rabindran R, Samiyappan R, Balasubramanian P, Velazhahan R (2012) Engineering resistance against Tobacco streak virus (TSV) in sunflower and tobacco using RNA interference. Biol Plant 56:735-741

Qiao F, Yang Q, Wang C, Fan Y, Wu X, Zhao K (2007) Modification of plant height via RNAi suppression of OsGA20ox2 gene in rice. Euphytica 158:35-45

Rathore KS, Sundaram S, Sunilkumar G, Campbell LM, Puckhaber L, Marcel S, Palle SR, Stipanovic RD, Wedegaertner TC (2012) Ultra-low gossypol cottonseed: generational stability of the seed-specific, RNAi-mediated phenotype and resumption of terpenoid profile following seed germination. Plant Biotechnol J 10:174-183

Redfern AD, Colley SM, Beveridge DJ, Ikeda N, Epis MR, Li X, Foulds CE, Stuart LM, Barker A, Russell VJ, Ramsay K, Kobelke SJ, Li X, Hatchell EC, Payne C, Giles KM, Messineo A, Gatignol A, Lanz RB, O’Malley BW, Leedman PJ (2013) RNAinduced silencing complex (RISC) proteins PACT, TRBP, and Dicer are SRA binding nuclear receptor coregulators. Proc Natl Acad Sci USA 110:6536-6541. doi:10.1073/pnas.1301620110

Regina A, Bird A, Topping D, Bowden S, Freeman J, Barsby T, Kosar-Hashemi B, Li Z, Rahman S, Morell M (2006) Highamylose wheat generated by RNA interference improves indices of large-bowel health in rats. Proc Natl Acad Sci USA 103:3546-3551

Regina A, Kosar-Hashemi B, Ling S, Li Z, Rahman S, Morell M (2010) Control of starch branching in barley defined through differential RNAi suppression of starch branching enzyme IIa and IIb. J Exp Bot 61:1469-1482

Reinhart BJ, Slack FJ, Basson M, Pasquinelli AE, Bettinger JC, Rougvie AE, Horvitz HR, Ruvkun G (2000) The 21-nucleotide let-7 RNA regulates developmental timing in Caenorhabditis elegans. Nature 403:901-906 
Reyes JL, Chua NH (2007) ABA induction of miR159 controls transcript levels of two MYB factors during Arabidopsis seed germination. Plant J 49:592-606

Riechen J (2007) Establishment of broad-spectrum resistance against Blumeria graminis f. sp. tritici in Triticum aestivum by RNAi mediated knock-down of MLO. J Verbr Leb. 2:120

Riley KJ, Yario TA, Steitz JA (2012) Association of Argonaute proteins and microRNAs can occur after cell lysis. RNA 18:1581-1585

Risco CA, Chase CC Jr (1997) Handbook of plant and fungal toxicants In: D’Mello JPF(ed) CRC Press, Boca Raton, pp 87-98

Rodoni BC, Dale JL, Harding RM (1999) Characterization and expression of the coat protein-coding region of the banana bract mosaic potyvirus, development of diagnostic assays and detection of the virus in banana plants from five countries in Southeast Asia. Arch Virol 144:1725-1737

Rubinelli PM, Chuck G, Li X, Meilan R (2013) Constitutive expression of the Corngrass 1 microRNA in poplar affects plant architecture and stem lignin content and composition. Biomass Bioenergy 54:312-321

Ruby JG, Jan CH, Bartel DP (2007) Intronic microRNA precursors that bypass Drosha processing. Nature 448:83-86

Ruiz-Ferrer V, Voinnet O (2007) Viral suppression of RNA silencing: $2 \mathrm{~b}$ wins the golden fleece by defeating argonaute. Bioassays 29:319-323

Sandhu APS, Abdelnoor RV, Mackenzie SA (2007) Transgenic induction of mitochondrial rearrangements for cytoplasmic male sterility in crop plants. Proc Natl Acad Sci USA 104:1766-1770

Schijlen EGWM, de Vos RCH, Martens S, Jonker HH, Rosin FM, Molthoff JW, Tikunov YM, Angenent GC, van Tunen AJ, Bovy AG (2007) RNA interference silencing of chalcone synthase, the first step in the flavonoid biosynthesis pathway, leads to parthenocarpic tomato fruits. Plant Physiol 144:1520-1530

Schwind N, Zwiebel M, Itaya A, Ding B, Wang M, Krczal G, Wassenegger M (2009) RNAi-mediated resistance to potato spindle tuber viroid in transgenic tomato expressing a viroid hairpin RNA construct. Mol Plant Pathol 10:459-469

Segal G, Song R, Messing J (2003) A new opaque variant of maize by a single dominant RNA-interference inducing transgene. Genetics 165:387-397

Seitz C, Vitten M, Steinbach P, Hartl S, Hirsche J, Rathje W, Treutter D, Forkmann G (2007) Redirection of anthocyanin synthesis in Osteospermum hybrida by a two-enzyme manipulation strategy. Phytochemistry 68:824-833

Senthil-Kumar M, Mysore KS (2011) New dimensions for VIGS in plant functional genomics. Trends Plant Sci 16:656-665

Sharma HC, Crouch JH, Sharma KK, Seetharama N, Hash CT (2002) Applications of biotechnology for crop improvement: prospects and constraints. Plant Sci 163:381-395

Shewry PR, Jones HD, Halford NG (2008) Plant biotechnology: transgenic crops. In: Stahl U, Donalies UEB, Nevoigt E (eds) Advances in biochemical engineering and biotechnology-food biotechnology. Springer, Berlin, pp 149-186

Shimada T, Otani M, Hamada T, Kim SH (2006) Increase of amylose content of sweet potato starch by RNA interference of the starch branching enzyme II gene (IbSBEII). Plant Biotechnol J 23:85-89

Shimizu T, Yoshii M, Wei T, Hirochika H, Omura T (2009) Silencing by RNAi of the gene for Pns12, a viroplasm matrix protein of Rice dwarf virus, resulted in strong resistance of transgenic rice plants to the virus. Plant Biotechnol J 7:24-32

Sieber P, Wellmer F, Gheyselinck J, Riechmann L, Meyerowitz EM (2007) Redundancy and specialization among plant microRNAs: role of the MIR164 family in developmental robustness. Development 134:1051-1060
Simón-Mateo C, García JA (2011) Antiviral strategies in plants based on RNA silencing. Biochim Biophys Acta 1809:722-731

Sindhu AS, Maier TR, Mitchum MG, Hussey RS, Davis EL, Baum TJ (2009) Effective and specific in planta RNAi in cyst nematodes: expression interference of four parasitism genes reduces parasitic success. J Exp Bot 60:315-324

Siritungam D, Sayre R (2003) Generation of cyanogen-free transgenic cassava. Planta 217:367-373

Small I (2007) RNAi for revealing and engineering plant gene functions. Curr Opin Biotechnol 18:148-153

Spencer PS, Roy DN, Ludolph A, Hugon J, Dwivedi MP, Schaumburg HH (1986) Lathyrism: evidence for role of the neuroexcitatory aminoacid BOAA. Lancet 2:1066-1067

Sun L, Yuan B, Zhang M, Wang L, Cui M, Wang Q, Leng P (2012) Fruit-specific RNAi-mediated suppression of SINCED1 increases both lycopene and b-carotene contents in tomato fruit. J Exp Bot. doi:10.1093/jxb/ers026

Sunilkumar G, Campbell LM, Puckhaber L, Stipanovic RD, Rathore KS (2006) Engineering cottonseed for use in human nutrition by tissue-specific reduction of toxic gossypol. Proc Natl Acad Sci USA 103:18054-18059

Sunkar R, Zhu JK (2004) Novel and stress-regulated micro RNAs and other small RNAs from Arabidopsis. Plant Cell 16:2001-2019

Sussex IM, Kerk NM (2001) The evolution of plant architecture. Curr Opin Plant Biol 4:33-37

Tehseen M, Imran M, Hussain M, Irum S, Ali S, Mansoor S, Zafar Y (2010) Development of male sterility by silencing Bcp1 gene of Arabidopsis through RNA interference. Afr J Biotechnol 9:2736-2741

Tester M, Langridge P (2010) Breeding technologies to increase crop production in a changing world. Science 327: $818-822$

Tiedjens VA (1928) Sex ratios in cucumber flowers as affected by different conditions of soil and light. J Agric Res. 36:721-746

Tomes DT (1997) Seedless hopes bode well for winter vegetables. Nat Biotechnol 15:1344-1345

Trindade I, Capita o C, Dalmay T, Fevereiro MP, dos Santos DM (2010) miR398 and miR408 are up-regulated in response to water deficit in Medicago truncatula. Planta 231:705-716

Tuschl T (2001) RNA interference and small interfering RNAs. ChemBioChem 2:239-245

Tyagi H, Rajasubramaniam S, Rajam MV, Dasgupta I (2008) RNAinterference in rice against rice tungro bacilliform virus results in its decreased accumulation in inoculated rice plants. Transgenic Res 17:897-904

Underwood BA, Tieman DM, Shibuya K, Dexter RJ, Loucas HM, Simkin AJ, Sims CA, Schmelz EA, Klee HJ, Clark DG (2005) Ethylene-regulated floral volatile synthesis in petunia corollas. Plant Physiol 138:255-266

Valdés-López O, Arenas-Huertero C, Ramírez M, Girard L, Sánchez F, Vance CP, Reyes JL, Hernández G (2008) Essential role of MYB transcription factor: PvPHR1 and microRNA: PvmiR399 in phosphorus-deficiency signaling in common bean roots. Plant Cell Environ 31:1834-1843

Vanitharani R, Chellappan P, Fauquet CM (2003) Short interfering RNA-mediated interference of gene expression and viral DNA accumulation in cultured plant cells. Proc Natl Acad Sci USA 100:9632-9636

Varoquaux F, Blanvillain R, Delseny M, Gallois P (2000) Less is better: new approaches for seedless fruit production. Trends Biotechnol 18:233-242

Vaucheret H (2006) Post-transcriptional small RNA pathways in plants: mechanisms and regulations. Genes Dev 20:759-771

Vaucheret H, Chupeau Y (2012) Ingested plant miRNAs regulate gene expression in animals. Cell Res 22:3-5 
Vierstra RD (2003) The ubiquitin/26S proteasome pathway, the complex last chapter in the life of many plant proteins. Trends Plant Sci 8:135-142

Vriezen WH, Feron R, Maretto F, Keijman J, Mariani C (2008) Changes in tomato ovary transcriptome demonstrate complex hormonal regulation of fruit set. New Phytol 177:60-76

Wang M, Abbott D, Waterhouse PM (2000) A single copy of a virus derived transgene encoding hairpin RNA gives immunity to barley yellow dwarf virus. Mol Plant Pathol 1:401-410

Wang Y, Ying J, Kuzma M, Chalifoux M, Sample A, McArthur C, Uchacz T, Sarvas C, Wan J, Dennis DT, McCourt P, Huang Y (2005) Molecular tailoring of farnesylation for plant drought tolerance and yield protection. Plant J 43:413-424

Wang Y, Beaith M, Chalifoux M, Ying J, Uchacz T, Sarvas C, Griffiths R, Kuzma M, Wan J, Huang Y (2009) Shoot-specific down-regulation of protein farnesyltransferase (alpha-subunit) for yield protection against drought in canola. Mol Plant 2:191-200

Wang L, Liu H, Li D, Chen H (2011a) Identification and characterization of maize microRNAs involved in the very early stage of seed germination. BMC Genom 12:154

Wang T, Chen L, Zhao M, Tian Q, Zhang WH (2011b) Identification of drought-responsive microRNAs in Medicago truncatula by genome-wide high-throughput sequencing. BMC Genom 12:367

Waterhouse PM, Graham HW, Wang MB (1998) Virus resistance and gene silencing in plants can be induced by simultaneous expression of sense and antisense RNA. Proc Natl Acad Sci USA 95:13959-13964

Wei S, Li X, Gruber MY, Li R, Zhou R, Zebarjadi A, Hannoufa A (2009) RNAi-mediated suppression of DET1 alters the levels of carotenoids and sinapate esters in seeds of Brassica napus. J Agric Food Chem 57:5326-5333

Weise SE, van Wijk KJ, Sharkey TD (2011) The role of transitory starch in C3, CAM, and C4 metabolism and opportunities for engineering leaf starch accumulation. J Exp Bot 62:3109-3118

Weise SE, Aung K, Jarou ZJ, Mehrshahi P, Li Z, Hardy AC, Carr DJ, Sharkey TD (2012) Engineering starch accumulation by manipulation of phosphate metabolism of starch. Plant Biotechnol J. doi:10.1111/j.1467-7652.2012.00684.x

Wesley SV, Helliwell CA, Smith NA, Wang MB, Rouse DT, Liu Q, Gooding PS, Singh SP, Abbott D, Stoutjesdijk PA, Robinson SP, Gleave AP, Green AG, Waterhouse PM (2001) Construct design for efficient, effective and high-throughput gene silencing in plants. Plant J 27:581-590

White PJ, Broadley MR (2009) Biofortification of crops with seven mineral elements often lacking in human diets-iron, zinc, copper, calcium, magnesium, selenium and iodine. New Phytol $182: 49-84$

WHO (2000) Turning the tide of malnutrition: responding to the challenge of the 21st century. Geneva: WHO, 2000 (WHO/NHD/00.7)

Wilson RC, Doudna JA (2013) Molecular Mechanisms of RNA Interference. Annu Rev Biophys 42:217-239

Wilson ZA, Morroll SM, Dawson J, Swarup R, Tighe PJ (2001) The Arabidopsis MALE STERILITY1 (MS1) gene is a transcriptional regulator of male gametogenesis, with homology to the PHDfinger family of transcription factors. Plant J 28:27-39

Wu G, Poethig RS (2006) Temporal regulation of shoot development in Arabidopsis thaliana by miR156 and its target SPL3. Development 133:3539

Wu G, Park MY, Conway SR, Wang JW, Weigel D, Poethig RS (2009) The sequential action of miR156 and miR172 regulates developmental timing in Arabidopsis. Cell 138:750-759

Xie G, Peng L (2011) Genetic engineering of energy crops: a strategy for biofuel production in China. J Int Plant Biol 53:143-150

Xin M, Wang Y, Yao Y, Xie C, Peng H, Ni Z, Sun Q (2010) Diverse set of microRNAs are responsive to powdery mildew infection and heat stress in wheat (Triticum aestivum L.). BMC Plant Biol 10:123
Xiong A, Yao Q, Peng R, Li X, Han P, Fan H (2005) Different effects on ACC oxidase gene silencing triggered by RNA interference in transgenic tomato. Plant Cell Rep 23:639-646

Xu G, Sui N, Tang Y, Xie K, Lai Y, Liu Y (2010) One-step, zero-background ligation-independent cloning intron-containing hairpin RNA constructs for RNAi in plants. New Phytol 187:240-250

Xu YZ, Santamaria RDLR, Virdi KS, Arrieta-Montiel MP, Razvi F, Li S, Ren G, Yu B, Alexander D, Guo L, Feng X, Dweikat IM, Clemente TE, Mackenzie SA (2012) The chloroplast triggers developmental reprogramming when MUTS HOMOLOG1 is suppressed in plants. Plant Physiol Prev. doi:10.1104/ pp.112.196055

Yadav BC, Veluthambi K, Subramaniam K (2006) Host-generated double stranded RNA induces RNAi in plant-parasitic nematodes and protects the host from infection. Mol Biochem Parasitol 148:219-222

Yan P, Shen W, Gao X, Li X, Zhou P, Duan J (2012) High-throughput construction of intron-containing hairpin RNA vectors for RNAi in plants. PLoS ONE. doi:10.1371/journal.pone.0038186

Yoder JI, Gunathilake P, Wu B, Tomilova N, Tomilov AA (2009) Engineering host resistance against parasitic weeds with RNA interference. Pest Manage Sci 65:460-466

Yoon EK, Yang JH, Lim J, Kim SH, Kim SK, Lee WS (2010) Auxin regulation of the microRNA390-dependent transacting small interfering RNA pathway in Arabidopsis lateral root development. Nucleic Acids Res 38:1382-1391

Yu B, Lydiate DJ, Young LW, Schafer UA, Hannoufa A (2007) Enhancing the carotenoid content of Brassica napus seeds by downregulating lycopene epsilon cyclase. Transgenic Res 17:573-585

Yuki Y, Mejima M, Kurokawa S, Hiroiwa T, Kong G, Kuroda M, Takahashi Y, Nochi T, Tokuhara D, Kohda T, Kozaki S, Kiyono H (2012) RNAi suppression of rice endogenous storage proteins enhances the production of rice-based of Botulinum neurotoxin type A vaccine. Vaccine 30:4160-4166

Zalewski W, Galuszka P, Gasparis S, Orczyk W, Nadolska-Orczyk A (2010) Silencing of the HvCKX1 gene decreases the cytokinin oxidase/dehydrogenase level in barley and leads to higher plant productivity. J Exp Bot 61:1839-1851

Zhang YY, Li HX, Shu WB, Zhang CJ, Ye ZB (2011) RNA interference of a mitochondrial APX gene improves vitamin $\mathrm{C}$ accumulation in tomato fruit. Scientia Hort. 129:220-226

Zhang JZ, Ai XY, Guo WW, Peng SA, Deng XX, Hu CG (2012a) Identification of miRNAs and their target genes using deep sequencing and degradome analysis in Trifoliate Orange [Poncirus trifoliate (L.) Raf]. Mol Biotechnol 51:44-57

Zhang L, Hou D, Chen X, Li D, Zhu L, Zhang Y, Li J, Bian Z, Liang X, Cai X, Yin Y, Wang C, Zhang T, Zhu D, Zhang D, Xu J, Chen Q, Ba Y, Liu J, Wang Q, Chen J, Wang J, Wang M, Zhang Q, Zhang J, Zen K, Zhang CY (2012b) Exogenous plant MIR168a specifically targets mammalian LDLRAP1: evidence of crosskingdom regulation by microRNA. Cell Res 22:107-126

Zhao BT, Liang RQ, Ge LF, Li W, Xiao HS, Lin HX, Ruan KC, Jin YX (2007) Identification of drought-induced microRNAs in rice. Biochem Biophy Res Comm 354:585-590

Zhou H, He SJ, Cao Y, Chen T, Du B, Chu C, Zhang J, Chen S (2006) OsGLU1, a putative membrane bound endo-1, 4-b-D-glucanase from rice, affects plant internode elongation. Plant Mol Biol 60:137-151

Zhou Y, Yuan Y, Yuan F, Wang M, Zhong H, Gu M, Liang G (2012) RNAi-directed down-regulation of RSV results in increased resistance in rice (Oryza sativa L.). Biotechnol Lett. doi: 10.1007/s10529-012-0848-0

Zhu D, Deng XW (2012) A non-coding RNA locus mediates environment-conditioned male sterility in rice. Cell Res 22:791-792 